"Past and Present in DeNOx catalysis. From Molecular Modelling to Chemical Engineering" , P. Granger and V. Parvulescu, Eds (Elsevier Sci. Publ.).

Stud. Surf. Sci. Catal., Vol 171. Chapter 8, p. 235-259 (2007).

DOI: 10.1016/S0167-2991(07)80209-6

\title{
The Role of Cerium-based Oxides used as Oxygen Storage Materials in DeNOx Catalysis
}

\author{
Xavier COURTOIS, Nicolas BION, Patrice MARECOT and \\ Daniel DUPREZ*
}

LACCO, Laboratoire de Catalyse en Chimie Organique, CNRS \& University of Poitiers, 40 Av. Recteur Pineau 86022 POITIERS Cedex, France.

* Corresponding author: Email: daniel.duprez@univ-poitiers.fr

\begin{abstract}
Materials with high "Oxygen Storage Capacity" (OSC) are now widely used in automotive converter catalysts. There are mainly composed of Ce-based oxides $(\mathrm{CeZrOx}, \mathrm{CeZrPrOx}, \ldots)$ having both multiple cationic valencies and oxygen vacancies. These properties allow the catalyst to store active $\mathrm{O}$ species $\left(\mathrm{O}^{2-}\right.$, superoxide, ...) in $\mathrm{O}_{2}$ excess and to release them when the $\mathrm{O}_{2}$ concentration in gas phase decreases or becomes nil. After having briefly examined the main properties of these OSC materials and the methods employed for their characterization, their impact in automotive catalysis will be reviewed, with a special insight in DeNOx catalysis: (i) in three-way catalysis (TWC) (ii) in automotive catalysis under lean conditions (lean-burn spark ignition engine and Diesel).
\end{abstract}




\section{Introduction}

Use of oxygen storage components in three-way catalysis was proposed by Ghandi et al. in 1976 [1] and implemented in the real exhaust catalysts at the beginning of the 80's. Since the pioneer's work of Yao and Yu Yao [2] and of Su et al. [3,4], numerous studies were devoted to a better knowledge of OSC properties of ceria-based compounds [5,6] and, specially, to $\mathrm{Ce}_{\mathrm{x}} \mathrm{Zr}_{1-\mathrm{x}} \mathrm{O}_{2}$ mixed oxides $[7,8,9,10]$. OSC compounds are known to enlarge the "operating window" of TWC, i.e. the $\lambda$ range within which $\mathrm{CO}$ and $\mathrm{HC}$ oxidation as well as NOx reduction can occur at the optimal rate (higher than 90\% conversion [11]). Although it can be inferred that OSC materials exhibit the highest impact under transient conditions, numerous investigations were carried out at the stationary state. However, kinetic studies carried out at various concentrations may give an idea of what can occur in transient regime.

\section{OSC measurements and Oxygen mobility}

\subsection{OSC measurements}

Oxygen storage capacity is generally measured in a pulse chromatographic reactor using $\mathrm{CO}[12,13,14,15,16]$ or, to a lesser extent $\mathrm{H}_{2}$ [17] as reducers. The procedure is depicted in Fig. 1. Pulses of $\mathrm{CO}\left(\right.$ or $\left.\mathrm{H}_{2}\right)$ are injected over the preoxidized sample. According to the nomenclature of $\mathrm{Yao}$ and $\mathrm{Yu} \mathrm{Yao}$, the $\mathrm{CO}_{2}$ produced upon the first CO pulse allows to calculate the Oxygen Storage Capacity while the total amount of $\mathrm{CO}_{2}$ formed upon several $\mathrm{CO}$ pulses (typically 10 pulses) gives the "Oxygen Storage Capacity, Complete" (OSCC). In most cases, only OSC is retained for characterizing TW catalysts [18]. 
Fig. 1 shows the typical behavior of a ceria-based sample. As a rule:

a- The reduction phase (phase 1) is slower than the re-oxidation one (phase 2): the $\mathrm{CO}_{2}$ formation decreases regularly upon each $\mathrm{CO}$ pulse while the re-oxidation is achieved upon the first pulse of $\mathrm{O}_{2}$. This is a rather general phenomenon in catalysis: oxides (like rare-earth oxides) reduced more slowly than their suboxides may be re-oxidized. It is interesting to note that the reverse phenomenon can be observed with the metals $(\mathrm{Pt}, \mathrm{Rh}, \mathrm{Pd})$ : their oxides are reduced at a much lower temperature than the metal can be re-oxidized $[19,20,21]$ even though the nature of support and the metal particle size may change the redox properties significantly $[20,22,23]$.

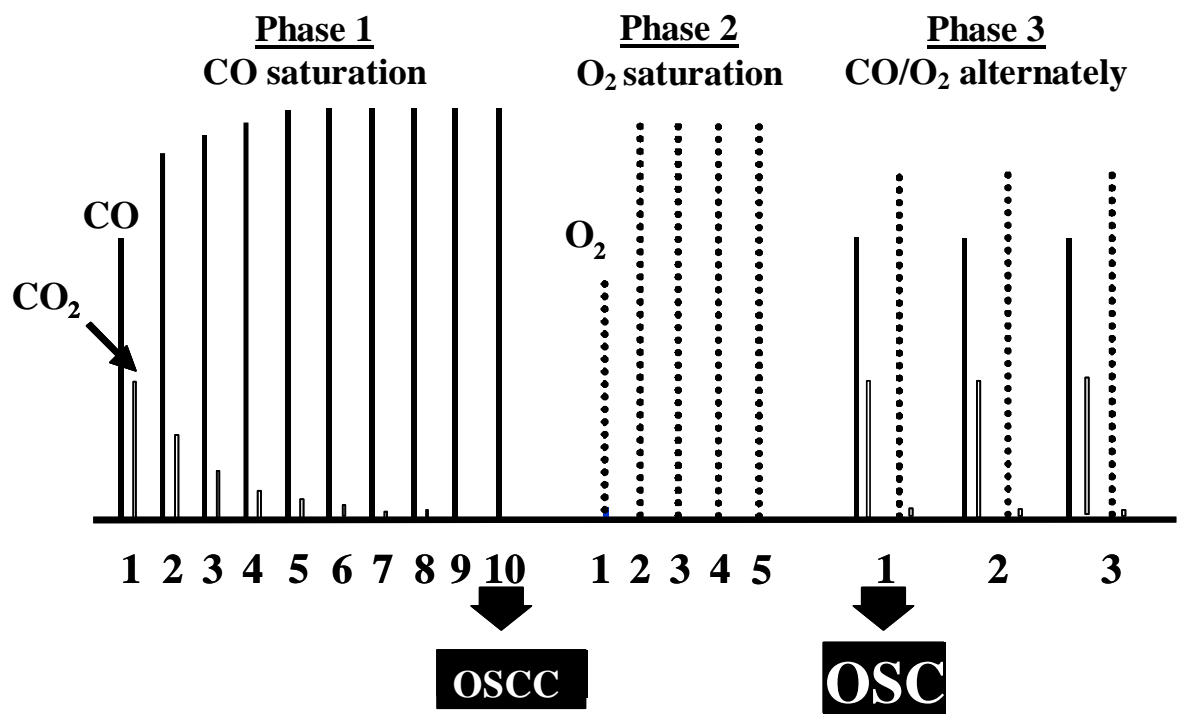

Fig. 1. General procedure for OSC measurements over TWC catalysts. CO and $\mathrm{CO}_{2}$ are separated over a small Porapak column inserted between the sample and the TC detector. The first $\mathrm{CO}$ pulse is injected over pre-oxidized sample. $\mathrm{CO}$ can be replaced by $\mathrm{H}_{2}$. 
b- Depending on the temperature, there may be a carbon deficit in the mass balance upon individual pulses, i.e. $\mathrm{CO}$ consumption may be higher than $\mathrm{CO}_{2}$ formation. A certain amount of carbon may be stored in the catalyst and released upon the following $\mathrm{CO}$ pulses or upon the first pulses of $\mathrm{O}_{2}$. In this case, some $\mathrm{CO}_{2}$ appears in phase 2. A detailed investigation of $\mathrm{C}$ and $\mathrm{O}$ mass balance during OSC measurements has been made by Holmgren et al [24].

c- In most cases, there is a good agreement between the OSC measured upon the first pulse of $\mathrm{CO}$ (phase 1) and the OSC deduced from alternate pulses $\mathrm{CO}$ and $\mathrm{O}_{2}$ (phase 3), which tends to prove that the catalysts show stable redox properties all along the procedure of measurement [25].

Several reaction steps may occur in the course of the oxygen storage process [24,26]:

1- Oxygen adsorption which may be dissociative (Eq. 1) or not (Eq. 2):

$$
\begin{aligned}
& 1 / 2 \mathrm{O}_{2}+\square_{\mathrm{s}} \rightarrow \mathrm{O}_{\mathrm{s}} \\
& \mathrm{O}_{2}+\square_{\mathrm{s}^{2-}} \rightarrow \mathrm{O}_{2}^{2-}
\end{aligned}
$$

where $\square_{\text {s }}$ represents a free vacant site which may be negatively charged as in Eq. 2. Dioxygen species, such as superoxides or peroxides, were evidenced by IR studies $[27,28,29]$.

2- Reaction between $\mathrm{CO}_{\mathrm{g}}$ and surface oxygen or dioxygen species to give $\mathrm{CO}_{2}$ (Eq. 3) or carbonates (Eq. 4)

$$
\begin{aligned}
& \mathrm{CO}_{\mathrm{g}}+\mathrm{O}_{\mathrm{s}} \rightarrow \mathrm{CO}_{2 \mathrm{~g}}+\square \\
& \mathrm{CO}_{\mathrm{g}}+\mathrm{O}_{2 \mathrm{~s}}^{2-} \rightarrow \mathrm{CO}_{3 \mathrm{~s}}^{2-}
\end{aligned}
$$

Surface carbonites, carbonates, inorganic carboxylates and sometimes formates (especially at low temperature) were identified by Fourier transform infrared (FTIR) [30,31]. 
3- Oxygen diffusion from the bulk sites to the surface

$$
\mathrm{O}_{\mathrm{b}}+\square_{\mathrm{s}} \rightarrow \mathrm{O}_{\mathrm{s}}+\square_{\mathrm{b}}
$$

4- Side reaction such as CO dissociation (Eq. 6), the Boudouard reaction (Eq. 7) or the water gas shift reaction (Eq. 8, with surface $\mathrm{OH}$ species) may also occur:

$$
\begin{aligned}
& \mathrm{CO}_{\mathrm{g}}+2 \square_{\mathrm{s}} \rightarrow \mathrm{C}_{\mathrm{s}}+\mathrm{O}_{\mathrm{s}} \\
& 2 \mathrm{CO}_{\mathrm{g}}+\square_{\mathrm{s}} \rightarrow \mathrm{C}_{\mathrm{s}}+\mathrm{CO}_{2} \\
& \mathrm{CO}_{\mathrm{g}}+\mathrm{OH}_{\mathrm{s}} \rightarrow \mathrm{CO}_{2}+1 / 2 \mathrm{H}_{2}+\square_{\mathrm{s}}
\end{aligned}
$$

On ceria or ceria-zirconia, $\mathrm{OH}_{\mathrm{s}}$ species are generally associated to the formation of $\mathrm{CeOOH}$ groups with a correlative reduction of the surface $[32,33]$.

\subsection{OSC of ceria and $\mathrm{Ce}_{x} \mathrm{Zr}_{1-x} \mathrm{O}_{2}$ oxides}

Selected OSC values are reported in Table 1 for ceria and cerium-zirconium mixed oxides. These results confirm that the isomorphous substitution of $\mathrm{Ce}^{4+}$ by $\mathrm{Zr}^{4+}$ ions clearly improves the catalyst stability. BET area of ceria treated at $900^{\circ} \mathrm{C}$ is close to $20 \mathrm{~m}^{2} \mathrm{~g}^{-1}$ while it amounts to $35-45 \mathrm{~m}^{2} \mathrm{~g}^{-1}$ for most mixed oxides prepared by coprecipitation or sol-gel methods. Theoretical OSC values may be calculated according to the following assumptions:

- Only $\mathrm{Ce}^{4+}$ is reduced into $\mathrm{Ce}^{3+}$ in the OSC process. $\mathrm{Zr}^{4+}$ virtually cannot be reduced.

- One oxygen atom out of four (among those which are associated with Ce ions) is available in the storage process. 
Table 1: OSC values of ceria and $\mathrm{Ce}_{\mathrm{x}} \mathrm{Zr}_{1-\mathrm{x}} \mathrm{O}_{2}$ oxides

\begin{tabular}{|c|c|c|c|c|c|c|c|}
\hline \multirow[t]{2}{*}{ Catalyst } & \multirow[t]{2}{*}{$\begin{array}{l}\text { Tox } \\
\left({ }^{\circ} \mathrm{C}\right)\end{array}$} & \multirow{2}{*}{$\begin{array}{c}\text { BET } \\
\text { area } \\
\left(\mathrm{m}^{2} \mathrm{~g}^{-1}\right)\end{array}$} & \multicolumn{2}{|c|}{ O Storage } & \multicolumn{2}{|c|}{$\begin{array}{c}\text { OSC } \\
(\mu \mathrm{mol} \mathrm{O})\end{array}$} & \multirow[t]{2}{*}{ Ref. } \\
\hline & & & Red. & ${ }^{\circ} \mathrm{C}$ & $\mathrm{g}^{-1}$ & $\mathrm{~m}^{-2}$ & \\
\hline $\mathrm{CeO}_{2}$ & $900(6 h)$ & 22 & $\mathrm{CO}$ & 400 & 71 & 3.2 & [9] \\
\hline $\mathrm{Ce}_{0.6} \mathrm{Zr}_{0.4} \mathrm{O}_{2}$ & $900(6 h)$ & 52 & $\mathrm{CO}$ & 400 & 232 & 4.5 & [9] \\
\hline $\mathrm{CeO}_{2} \mathrm{NP}^{\mathrm{a}}$ & $900(4 h)$ & 13 & $\mathrm{CO}$ & 400 & 64 & 4.9 & [10] \\
\hline $\mathrm{Ce}_{0.9} \mathrm{Zr}_{0.1} \mathrm{O}_{2} \mathrm{NP}^{\mathrm{a}}$ & $900(4 h)$ & 18 & $\mathrm{CO}$ & 400 & 125 & 6.9 & [10] \\
\hline $\mathrm{Ce}_{0.75} \mathrm{Zr}_{0.25} \mathrm{O}_{2} \mathrm{NP}^{\mathrm{a}}$ & $900(4 h)$ & 19 & $\mathrm{CO}$ & 400 & 112 & 5.9 & [10] \\
\hline $\mathrm{Ce}_{0.9} \mathrm{Zr}_{0.1} \mathrm{O}_{2} \mathrm{SG}^{\mathrm{b}}$ & $900(4 h)$ & 43 & $\mathrm{CO}$ & 400 & 252 & 5.9 & [10] \\
\hline $\mathrm{Ce}_{0.75} \mathrm{Zr}_{0.25} \mathrm{O}_{2} \mathrm{SG}^{\mathrm{b}}$ & $900(4 h)$ & 32 & $\mathrm{CO}$ & 400 & 217 & 6.8 & [10] \\
\hline $\mathrm{Pt} / \mathrm{CeO}_{2}$ & $500(1 \mathrm{~h})$ & 49 & $\mathrm{CO}$ & 600 & 250 & 5.1 & [13] \\
\hline $\mathrm{Pt} / \mathrm{Ce}_{0.75} \mathrm{Zr}_{0.25} \mathrm{O}_{2}$ & $500(1 \mathrm{~h})$ & 72 & $\mathrm{CO}$ & 600 & 723 & 10 & [13] \\
\hline $\mathrm{Pt} / \mathrm{CeO}_{2}$ & $1000(1 \mathrm{~h})$ & 2 & $\mathrm{CO}$ & 600 & 150 & 75 & [13] \\
\hline $\mathrm{Pt} / \mathrm{Ce}_{0.75} \mathrm{Zr}_{0.25} \mathrm{O}_{2}$ & $1000(1 \mathrm{~h})$ & 14 & $\mathrm{CO}$ & 600 & 522 & 37 & [13] \\
\hline $\mathrm{CeO}_{2}^{\mathrm{c}, \mathrm{d}}$ & $377(2 \mathrm{~h})$ & $5-18$ & $\mathrm{H}_{2}$ & 377 & 70 & 6.1 & [17] \\
\hline $\mathrm{Ce}_{0.9} \mathrm{Zr}_{0.1} \mathrm{O}_{2}^{\mathrm{c}, \mathrm{d}}$ & 377 (2h) & $20-25$ & $\mathrm{H}_{2}$ & 377 & 280 & 12.4 & [17] \\
\hline $\mathrm{Ce}_{0.65} \mathrm{Zr}_{0.35} \mathrm{O}_{2}{ }^{\mathrm{c}, \mathrm{d}}$ & $377(2 \mathrm{~h})$ & $14-18$ & $\mathrm{H}_{2}$ & 377 & 360 & 22.5 & [17] \\
\hline $\mathrm{CeO}_{2}^{\mathrm{c}, \mathrm{e}}$ & 377 (2h) & $5-18$ & $\mathrm{H}_{2}$ & 377 & 1.2 & 0.10 & [17] \\
\hline $\mathrm{Ce}_{0.9} \mathrm{Zr}_{0.1} \mathrm{O}_{2}^{\mathrm{c}, \mathrm{e}}$ & $377(2 \mathrm{~h})$ & $20-25$ & $\mathrm{H}_{2}$ & 377 & 13 & 0.58 & [17] \\
\hline $\mathrm{Ce}_{0.65} \mathrm{Zr}_{0.35} \mathrm{O}_{2}^{\mathrm{c}, \mathrm{e}}$ & 377 (2h) & $14-18$ & $\mathrm{H}_{2}$ & 377 & 7.5 & 0.47 & [17] \\
\hline
\end{tabular}

${ }^{2}$ prepared by nitrate precipitation

${ }^{\mathrm{b}}$ prepared by a sol-gel technique ( $\mathrm{Zr}$ propoxide)

$c$ prepared by ball milling of oxides

d total OSC (value close to OSCC)

${ }^{e}$ dynamic OSC (pulse of $\mathrm{H}_{2}$ ) 
The theoretical surface density of oxygen ions was evaluated by Madier et al. for different crystallographic planes of $\mathrm{CeO}_{2}$ and $\mathrm{Ce}_{\mathrm{x}} \mathrm{Zr}_{1-\mathrm{x}} \mathrm{O}_{2}$ oxides [14]. For ceria, the theoretical $\mathrm{O}$ density would be of 13.7, 9.7 and 15.8 at.O $\mathrm{nm}^{-2}$ for (100), (110) and (111) surfaces respectively, which gives a mean surface density of 13.1 at.O $\mathrm{nm}^{-2}$ if one assumes an equidistribution of the three crystallographic planes. This figure leads to a theoretical OSC of $5.4 \mu \mathrm{mol} \mathrm{O} \mathrm{m}^{-2}$. The hypothesis of equidistribution may be not valid in all cases which can explains some difference in the reported results. Note that the (111) surface is thermodynamically the most stable.[34,35]

Due to the decrease of the lattice parameter upon $\mathrm{Zr}$ substitution, $\mathrm{O}$ surface density increases with the $\mathrm{Zr}$ content in the materials (see Ref. [36] for a review on the micro and nanostructures of $\mathrm{Ce}_{\mathrm{x}} \mathrm{Zr}_{1-\mathrm{x}} \mathrm{O}_{2}$ mixed oxides). The mean oxygen surface density may be approximated by the following equation:

$$
\mathrm{S}_{\mathrm{O}}\left(\mathrm{atOnm}^{-2}\right)=13.07+1.28(1-\mathrm{x})
$$

which leads to a theoretical OSC of:

$$
\operatorname{OSC}_{\text {th }}\left(\mu \mathrm{mol} \mathrm{O} \mathrm{m}{ }^{-2}\right)=5.43 \mathrm{x}+0.531 \mathrm{x}(1-\mathrm{x})
$$

The values of $\mathrm{OSC}_{\mathrm{th}}$ for the compounds listed in Table 1 are given in Table 2.

Table 2: Theoretical OSC values of $\mathrm{Ce}_{\mathrm{x}} \mathrm{Zr}_{1-\mathrm{x}} \mathrm{O}_{2}$ mixed oxides corresponding to the reduction of one surface layer.

\begin{tabular}{lccccc}
\hline $\mathrm{x}$ & 1 & 0.9 & 0.75 & 0.65 & 0.60 \\
\hline $\mathrm{OSC}_{\text {th }}\left(\mu \mathrm{mol} \mathrm{O} \mathrm{m}{ }^{-2}\right)$ & 5.43 & 4.93 & 4.17 & 3.65 & 3.39 \\
\hline
\end{tabular}


If one compares the data of Table 1 with the theoretical OSC values given in Table 2 (for one $\mathrm{O}$ layer), it appears that:

- the main effect of substituting $\mathrm{Ce}$ by $\mathrm{Zr}$ is to increase the thermal stability of the materials in significant proportion.

- OSC of $\mathrm{Ce}_{\mathrm{x}} \mathrm{Zr}_{1-\mathrm{x}} \mathrm{O}_{2}$ mixed oxides is higher than that of pure ceria. It may also be higher than the theoretical OSC, which proves that several oxygen layers can be involved in the storage process

Comparison of OSC evolutions with temperature for $\mathrm{CeO}_{2}\left(25 \mathrm{~m}^{2} \mathrm{~g}^{-1}\right)$ and $\mathrm{Ce}_{0.63} \mathrm{Zr}_{0.37} \mathrm{O}_{2}$ oxide $\left(43 \mathrm{~m}^{2} \mathrm{~g}^{-1}\right)$ was reported by Bedrane et al. [15,37]. Fig. 2 summarizes the specific behavior of these compounds in the oxygen storage process. Up to $300^{\circ} \mathrm{C}$, there is virtually no difference between OSC properties of ceria or of $\mathrm{Ce}_{0.63} \mathrm{Zr}_{0.37} \mathrm{O}_{2}$. By contrast, above $300^{\circ} \mathrm{C}$, OSC of the mixed oxide dramatically increases while that of pure ceria remains practically constant.

OSC values at 400 and $500^{\circ} \mathrm{C}$ for the two samples are compared in Table 3. At these temperatures, the layer number " $n$ " involved in the reduction process is significantly higher for the mixed oxide than for ceria. At $500^{\circ} \mathrm{C}$, more than three cerium ion layers (i.e. almost 2 cells) are reduced upon the first pulse of CO.

Table 3: Comparison of OSC of ceria and $\mathrm{Ce}_{0.63} \mathrm{Zr}_{0.37} \mathrm{O}_{2}$ at 400 and $500^{\circ} \mathrm{C}$.

\begin{tabular}{llcccccc}
\hline Oxide & OSCth & \multicolumn{3}{c}{ OSC $400^{\circ} \mathrm{C}(\mu \mathrm{mol})$} & \multicolumn{3}{c}{ OSC $500^{\circ} \mathrm{C}(\mu \mathrm{mol})$} \\
\cline { 2 - 8 } & $\mathrm{m}^{-2}$ & $\mathrm{~g}^{-1}$ & $\mathrm{~m}^{-2}$ & $\mathrm{n}$ & $\mathrm{g}^{-1}$ & $\mathrm{~m}^{-2}$ & $\mathrm{n}$ \\
\hline $\mathrm{CeO}_{2}$ & 5.43 & 49 & 1.96 & 0.36 & 64 & 2.56 & 0.47 \\
$\mathrm{Ce}_{0.63} \mathrm{Zr}_{0.37} \mathrm{O}_{2}$ & 3.54 & 167 & 3.88 & 1.10 & 480 & 11.2 & 3.2 \\
\hline
\end{tabular}




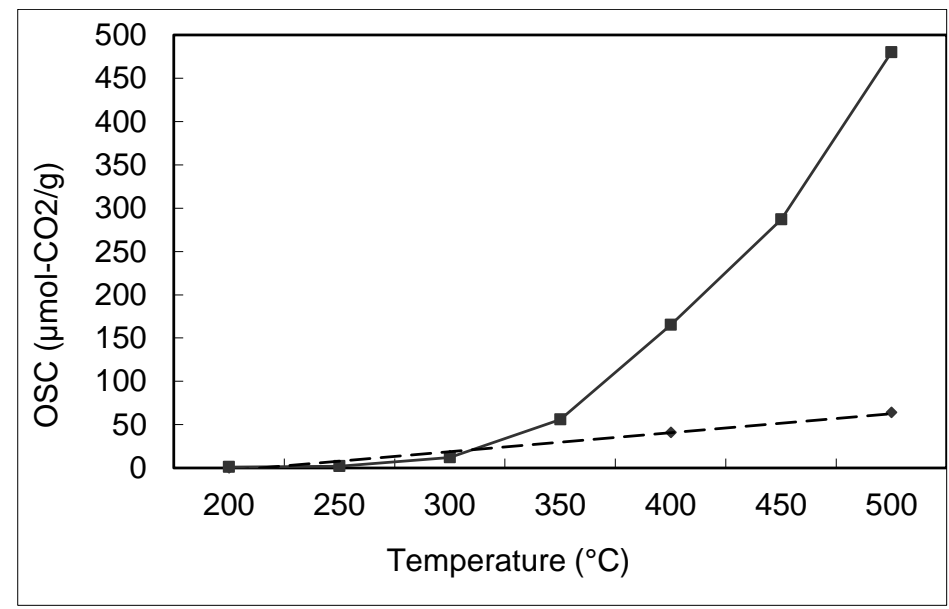

Fig. 2. Evolution of the OSC for $\mathrm{CeO}_{2}(\diamond)$ and $\mathrm{Ce}_{0,63} \mathrm{Zr}_{0,37} \mathrm{O}_{2}$

\subsection{Correlation with oxygen mobility}

Oxygen diffusion (Eq. 5) being a crucial step in the global oxygen storage process, OSC measurements have been tentatively correlated to oxygen mobility measured by ${ }^{18} \mathrm{O} /{ }^{16} \mathrm{O}$ isotopic exchange. The principle has been described in detail elsewhere $[14,38,39,40]$. It is based on the exchange between gaseous ${ }^{18} \mathrm{O}_{2}$ and ${ }^{16} \mathrm{O}$ species of the support via the metal particles (Fig. 3).

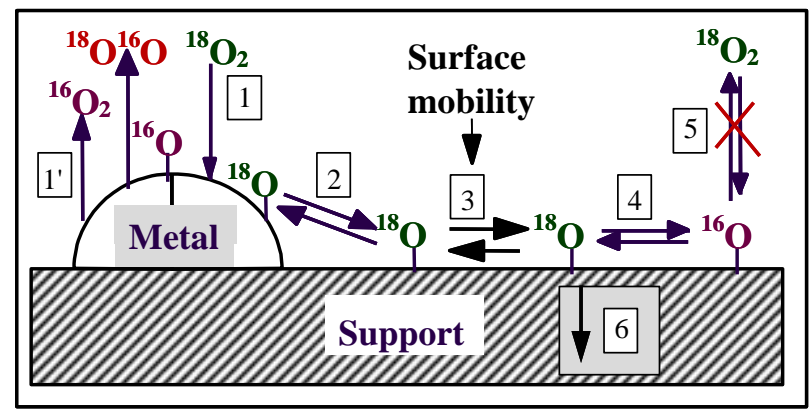

Fig. 3. Measurement of surface diffusion by isotopic exchange. 
The reaction is carried out in close-loop reactor connected to a mass spectrometer for ${ }^{18} \mathrm{O}_{2},{ }^{18} \mathrm{O}^{16} \mathrm{O}$ and ${ }^{16} \mathrm{O}_{2}$ analyses as a function of time [38]. The gases should be in equilibrium with the metallic surface (fast adsorption/desorption steps: 1 and 1 '). If the bulk diffusion is slow (step 6) and the direct exchange (step 5) does occur at a negligible rate, coefficients of surface diffusion $\mathrm{D}_{\mathrm{S}}$ can be calculated from the simple relationship between the number of exchanged atoms $\mathrm{N}_{\mathrm{e}}$ and $\sqrt{\mathrm{t}}$ given by the model of circular sources developed by Kramer and Andre [41]:

$$
\mathrm{N}_{\mathrm{e}}=\frac{2}{\sqrt{\pi}} \mathrm{C}_{\mathrm{m}}^{18} \mathrm{I}_{0} \sqrt{\mathrm{D}_{\mathrm{s}} \mathrm{t}}
$$

where $\mathrm{I}_{0}$ is the length of the metal/support interface, i.e. the total perimeter of the metal particles per $\mathrm{m}^{2}$ of catalyst, and $\mathrm{C}_{\mathrm{m}}^{18}$ is the surface concentration (at. $\mathrm{m}^{-2}$ ) of ${ }^{18} \mathrm{O}$ atoms on the metal. The specific particle perimeter $\mathrm{I}_{0}$ is a function of the metal loading $\mathrm{x}_{\mathrm{m}} \%$ and the dispersion $\mathrm{D} \%$ :

$$
\mathrm{I}_{0}=\beta \mathrm{x}_{\mathrm{m}} \mathrm{D}^{2}
$$

where $\beta$ is a parameter depending on nature of metal and particle shape. For most metal, $\beta$ is comprised between $2 \times 10^{5}$ and $10^{6} \mathrm{~m} \mathrm{~g}^{-1}[40,42]$ so that the specific perimeter of particles can be greater than $10^{8} \mathrm{~m} \mathrm{~g}^{-1}$. This huge length allows understanding the critical role played by the metal/surface junction in diffusion processes and in catalysis. Eq. 11 is generally applied in the first seconds of exchange: $\mathrm{C}_{\mathrm{m}}^{18}$ is then close to the metal surface concentration, all adsorbed $\mathrm{O}$ atoms being ${ }^{18} \mathrm{O}$ atoms. Some results obtained by Martin and Duprez [38] with this isotopic exchange technique are reported in Table 4. 
Table 4: Relative oxygen surface mobility for some oxides at $400^{\circ} \mathrm{C}$ (base 10 for alumina). The coefficient of surface diffusion for alumina is $2 \times 10^{-18} \mathrm{~m}^{2} \mathrm{~s}^{-1}$.

\begin{tabular}{lcc}
\hline Oxides & $\begin{array}{c}\text { BET area } \\
\mathrm{m}^{2} \mathrm{~g}^{-1}\end{array}$ & $\begin{array}{c}\text { Relative oxygen mobility at } \\
400^{\circ} \mathrm{C}\end{array}$ \\
\hline $\mathrm{CeO}_{2}$ & 60 & 2300 \\
$\mathrm{MgO}$ & 150 & 50 \\
$\mathrm{ZrO}_{2}$ & 40 & 28 \\
$\mathrm{CeO}_{2} / \mathrm{Al}_{2} \mathrm{O}_{3}$ & 100 & 18 \\
$\mathrm{Al}_{2} \mathrm{O}_{3}$ & 100 & 10 \\
$\mathrm{SiO}_{2}$ & 200 & 0.1 \\
\hline
\end{tabular}

Ceria shows the highest coefficient of diffusion in the rage of $10^{-15}$ to $10^{-16} \mathrm{~m}^{2} \mathrm{~s}^{-1}$, which is coherent with the high OSC values obtained with this oxide.

When surface diffusion is the only process of exchange, $\alpha_{\mathrm{g}}$ tends to an equilibrium value $\alpha^{*}$ at $\mathrm{t} \rightarrow \infty$. In most cases, after a rapid step of surface diffusion, it can be observed that $\alpha_{\mathrm{g}}$ continues slowly decreasing. This phenomenon corresponds to a slow step of bulk diffusion (coefficient $\mathrm{D}_{\mathrm{b}}$ ). A model of bulk diffusion in spherical grains was developed by Kakioka et al which led to the following equation [43]:

$$
-\operatorname{Ln} \frac{\alpha_{\mathrm{g}}}{\alpha^{*}}=\frac{2}{\sqrt{\pi}} \frac{\rho \mathrm{A}}{\mathrm{N}_{\mathrm{g}}} \sqrt{\mathrm{D}_{\mathrm{b}} \mathrm{t}}
$$

where $\mathrm{A}$ is the BET area of the oxide used as support and $\rho$ its density. Eq. 11 and 13 can be applied for oxides showing a relatively low surface diffusion step. Measurement of $D_{b}$ could be carried out with alumina and zirconia and was found in the range of $10^{-22}$ to $10^{-23} \mathrm{~m}^{2} \mathrm{~s}^{-1}$ [38]. Interestingly, it was noticed that the bulk $\mathrm{O}$ diffusion was an order of magnitude higher in zirconia than in alumina. With ceria, measurement of $D_{b}$ by Eq. 13 is not possible because of the very fast surface diffusion process, which did not allow discriminating the two regimes of diffusion. 
The problem is still more complex with ceria-zirconia samples for which both surface and bulk diffusion occur at a very high rate. A spatio-temporal 3D model was then developed in which all the physical steps (adsorption, desorption, surface and bulk diffusion) involved in the exchange process are taken into account simultaneously $[44,45]$. A program based on this model was developed and used to determine coefficients of surface and bulk diffusion in CeZrOx-supported metal catalysts. Some results are reported in Table 5 for three Pt/CeZrOx samples [46].

Table 5: Coefficients of diffusion of $\mathrm{Pt} / \mathrm{CeZrOx}$ catalysts [46].

\begin{tabular}{cccc}
\hline Catalyst & Pt/CZ-O & Pt/CZ-R & Pt/CZ-D \\
$\begin{array}{c}\text { BET area }\left(\mathrm{m}^{2} \mathrm{~g}^{-1}\right) \\
\text { Metal particle size }(\mathrm{nm})\end{array}$ & 104 & 3 & 37 \\
\hline $\begin{array}{c}\text { Temperature }\left({ }^{\circ} \mathrm{C}\right) \text { of } \\
\text { exchange }\end{array}$ & 323 & 332 & 334 \\
\hline $\begin{array}{c}\text { Surface diffusion } \mathrm{D}_{\mathrm{s}} \\
\left(\times 10^{-20} \mathrm{~m}^{2} \mathrm{~s}^{-1}\right)\end{array}$ & 109 & 1450 & 1.7 \\
\hline $\begin{array}{c}\text { Bulk diffusion } \mathrm{D}_{\mathrm{b}} \\
\left(\times 10^{-23} \mathrm{~m}^{2} \mathrm{~s}^{-1}\right)\end{array}$ & 4.5 & 36 & 0.34 \\
\hline
\end{tabular}

CZ-O is a conventional mixed oxide prepared by hydrolysis of $\mathrm{ZrO}\left(\mathrm{NO}_{3}\right)_{2}$ with an aqueous ammonia solution in the presence of a fine ceria powder. CZ-R was obtained by a reducing treatment in $\mathrm{CO}$ at $1200^{\circ} \mathrm{C}$ while $\mathrm{CZ}-\mathrm{D}$ was prepared by high energy ball milling of $\mathrm{CeO}_{2}$ and $\mathrm{ZrO}_{2}$ powders. This study confirmed that a high temperature of reduction can induce an extremely high mobility in CeZrOx oxides [36].

${ }^{18} \mathrm{O} /{ }^{16} \mathrm{O}$ isotopic exchange can detect the presence of binuclear oxygen species (superoxide $\mathrm{O}_{2}^{-}$, peroxide $\mathrm{O}_{2}^{2-}$ ). When $\mathrm{O}_{2}$ adsorption leads to the formation of 
such species, exchange proceeds via a "multiple exchange" mechanism in which two atoms at once are exchanged:

${ }^{18} \mathrm{O}_{2 \mathrm{~g}}+\left[{ }^{16} \mathrm{O} \bullet \bullet{ }^{16} \mathrm{O}\right]_{\mathrm{s}} \rightarrow{ }^{16} \mathrm{O}_{2 \mathrm{~g}}+\left[{ }^{18} \mathrm{O} \bullet{ }^{18} \mathrm{O}\right]_{\mathrm{s}}$

While ${ }^{16} \mathrm{O}^{18} \mathrm{O}$ is the primary product of exchange in the simple mechanism (exchange atom per atom), ${ }^{16} \mathrm{O}_{2}$ is the primary product when exchange occurs via a multiple mechanism $[14,40,47]$. This type of mechanism could be linked to the presence of superoxides species which can be detected by FTIR (bands at 1126 $\mathrm{cm}^{-1}$ ) $[48,49]$. At the beginning of exchange, the ratio $\mathrm{P}_{32} / \mathrm{P}_{34}$ is close to 1 on ceria, which means that both mechanisms (simple and multiple) occur with an equal probability. On ceria-zirconia, this ratio is much higher than unity, which implies that the multiple mechanism is predominant [14]. In parallel, exchange of superoxide species can be followed by FTIR. It was shown that $\left[{ }^{16} \mathrm{O}-{ }^{16} \mathrm{O}\right]^{-}$species exchange directly into $\left[{ }^{18} \mathrm{O}-{ }^{18} \mathrm{O}\right]^{-}$ones without intermediary formation of $\left[{ }^{18} \mathrm{O}-\right.$ $\left.{ }^{16} \mathrm{O}\right]^{-}$(Fig. 4). Finally, a clear correlation was observed between OSC and intensity of the band at $1126 \mathrm{~cm}^{-1}$.

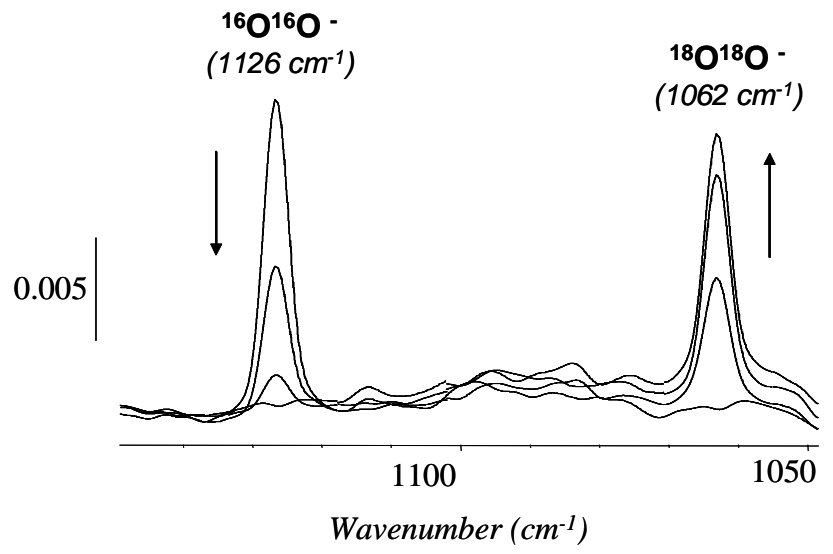

Fig. 4. FTIR spectra of adsorbed superoxide species during exchange of preoxidized $\mathrm{Ce}_{0.63} \mathrm{Zr}_{0.37} \mathrm{O}_{2}$ with ${ }^{18} \mathrm{O}_{2}$. [14] 


\section{Impact of OSC materials in Three-way catalysts}

OSC materials are able to increase the efficiency by enlarging the operating window of TW catalysts [50,51]. NOx reduction in TW catalysts is closely coupled to oxidation reactions since there is a competition between $\mathrm{NOx}$ and $\mathrm{O}_{2}$ reaction on the reducers present in the exhaust gases [52]. We will first examine the effect of these OSC materials on the oxidation efficiency of TW catalysts.

3.1. Impact of OSC on oxidation activity. Steam effects.

Ceria-based OSC compounds may have an impact on oxidation reactions especially when the catalysts are working around the stoichiometry (as this is the case under TW conditions). One of the first systematic studies was reported by $\mathrm{Yu}$ Yao [53,54]. Most results were obtained in $\mathrm{O}_{2}$ excess $\left(0.5 \% \mathrm{CO}+0.5 \% \mathrm{O}_{2}\right.$ or $0.1 \% \mathrm{HC}+1 \% \mathrm{O}_{2}$ ). Several series of $\mathrm{Pt}, \mathrm{Pd}$ and $\mathrm{Rh} / \mathrm{Al}_{2} \mathrm{O}_{3}$ of various dispersion, as well as metal foils, were investigated in $\mathrm{CO}$, alkane and alkene oxidation. The effect of metal dispersion in $\mathrm{CO}$ and propane oxidation are shown on Fig. 5. 


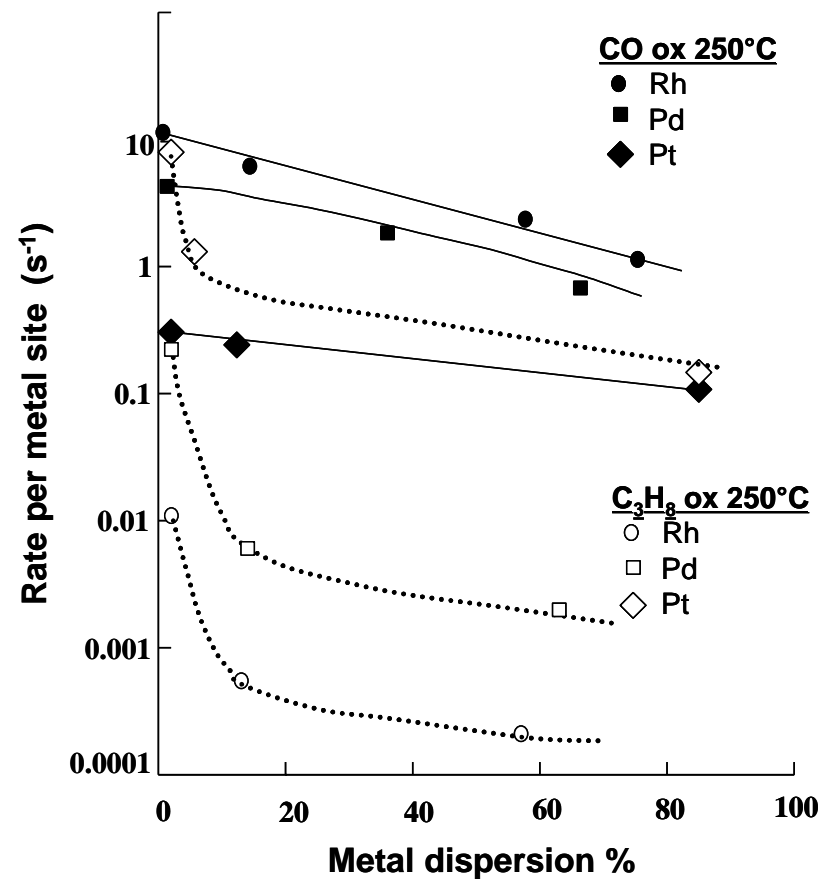

Fig. 5. Effect of metal dispersion on turnover frequencies in $\mathrm{CO}$ and propane oxidation ( $\mathrm{M} / \mathrm{Al}_{2} \mathrm{O}_{3}$ catalysts). Adapted from the data of $\mathrm{Yu} \mathrm{Yao}[53,54]$.

In every case, large particles of metal are more active in oxidation than the smallest ones. $\mathrm{CO}$ oxidation is moderately structure-sensitive (less than one order of magnitude between metal foil and much dispersed catalysts). By contrast, propane oxidation (and in general oxidation of small alkanes) are strongly structure-sensitive (two orders of magnitude between large and small particles). Rate equations were also expressed as a function of activation energy, E, and kinetic orders with respect to $\mathrm{O}_{2}(\mathrm{~m})$ and to $\mathrm{CO}$ or $\mathrm{HC}(\mathrm{n})$ :

$$
\mathrm{r}=\mathrm{k}_{0} \exp \left(-\frac{\mathrm{E}}{\mathrm{RT}}\right) \mathrm{P}_{\mathrm{O} 2}^{\mathrm{m}} \mathrm{P}_{\mathrm{CO}(\mathrm{HC})}^{\mathrm{n}}
$$

A summary of the results is given in Table 6. Also reported in the Table are the ratios $\eta$ between the specific activity of $\mathrm{M} / \mathrm{CeO}_{2}-\mathrm{Al}_{2} \mathrm{O}_{3}$ and $\mathrm{M} / \mathrm{Al}_{2} \mathrm{O}_{3}$ catalysts. 
Kinetic orders in $\mathrm{CO}$ oxidation on $\mathrm{M} / \mathrm{Al}_{2} \mathrm{O}_{3}$ can be explained by the classical Langmuir-Hinshelwood expression for the rate equation, as a function of the rate constant $\mathrm{k}$, the adsorption constants $\mathrm{K}$ and the partial pressures $\mathrm{P}$ :

$$
\mathrm{r}=\mathrm{k} \frac{\mathrm{K}_{\mathrm{O}} \mathrm{P}_{\mathrm{O}} \mathrm{K}_{\mathrm{CO}} \mathrm{P}_{\mathrm{CO}}}{\left(1+\mathrm{K}_{\mathrm{O}} \mathrm{P}_{\mathrm{O}}+\mathrm{K}_{\mathrm{CO}} \mathrm{P}_{\mathrm{CO}}\right)^{2}}
$$

Table 6: Kinetic parameters of $\mathrm{CO}$, propane and propene oxidation over $\mathrm{M} / \mathrm{Al}_{2} \mathrm{O}_{3}$ and $\mathrm{M} / \mathrm{CeO}_{2}-\mathrm{Al}_{2} \mathrm{O}_{3}$ catalysts $(\mathrm{M}=\mathrm{Pt}$, $\mathrm{Pd}$ or $\mathrm{Rh})$.

\begin{tabular}{|c|c|c|c|c|c|c|c|c|c|}
\hline \multirow[b]{3}{*}{$\mathrm{Pt} / \mathrm{Al}$} & \multicolumn{3}{|c|}{$\mathrm{CO}$} & \multicolumn{3}{|c|}{$\mathrm{C}_{3} \mathrm{H}_{8}$} & \multicolumn{3}{|c|}{$\mathrm{C}_{3} \mathrm{H}_{6}$} \\
\hline & $\mathrm{E}$ & $\mathrm{m}$ & $\mathrm{n}$ & $\mathrm{E}$ & $\mathrm{m}$ & $\mathrm{n}$ & $E$ & $\mathrm{~m}$ & $\mathrm{n}$ \\
\hline & $104-125$ & +1.0 & -0.9 & $84-105$ & -1.0 & +2.0 & $67-125$ & +2.0 & -1.0 \\
\hline $\mathrm{Pt} / \mathrm{Ce}-\mathrm{Al}$ & 84 & +0.5 & +0.3 & 96 & -1.0 & +2.0 & 80 & +1.5 & -0.6 \\
\hline $\mathrm{Pd} / \mathrm{Al}$ & $108-133$ & +0.9 & -0.9 & $66-96$ & +0.1 & +0.6 & $63-117$ & +1.5 & -0.5 \\
\hline $\mathrm{Pd} / \mathrm{Ce}-\mathrm{Al}$ & 50 & 0 & +1.0 & 63 & +0.1 & +0.6 & 63 & +0.7 & -0.3 \\
\hline $\mathrm{Rh} / \mathrm{Al}$ & $92-113$ & +1.0 & -0.8 & 100 & 0 & +0.5 & $67-92$ & -0.8 & +0.9 \\
\hline $\mathrm{Rh} / \mathrm{Ce}-\mathrm{Al}$ & 104 & 0 & +0.2 & 84 & +0.1 & +0.4 & 92 & 0 & +0.5 \\
\hline$\eta \mathrm{Pt}$ & \multicolumn{3}{|c|}{$2\left(250^{\circ} \mathrm{C}\right)$} & \multicolumn{3}{|c|}{$0.5\left(250^{\circ} \mathrm{C}\right)$} & \multicolumn{3}{|c|}{$3\left(300^{\circ} \mathrm{C}\right)$} \\
\hline$\eta \mathrm{Pd}$ & \multicolumn{3}{|c|}{$1\left(250^{\circ} \mathrm{C}\right)$} & \multicolumn{3}{|c|}{$0.2\left(350^{\circ} \mathrm{C}\right)$} & \multicolumn{3}{|c|}{$0.5\left(250^{\circ} \mathrm{C}\right)$} \\
\hline$\eta \mathrm{Rh}$ & \multicolumn{3}{|c|}{$5\left(250^{\circ} \mathrm{C}\right)$} & \multicolumn{3}{|c|}{$3\left(400^{\circ} \mathrm{C}\right)$} & \multicolumn{3}{|c|}{$2\left(300^{\circ} \mathrm{C}\right)$} \\
\hline
\end{tabular}

On alumina, there is a competition between $\mathrm{CO}$ and $\mathrm{O}_{2}$ adsorption on the same metal sites. As $\mathrm{CO}$ is much more strongly adsorbed than $\mathrm{O}_{2}$ on $\mathrm{Pt}, \mathrm{Pd}$ and $\mathrm{Rh}$, one has: $1+\mathrm{K}_{\mathrm{O}} \mathrm{P}_{\mathrm{O}} \ll \mathrm{K}_{\mathrm{CO}} \mathrm{P}_{\mathrm{CO}}$ and Eq. 16 reduces to:

$$
\mathrm{r}=\mathrm{k} \frac{\mathrm{K}_{\mathrm{O}} \mathrm{P}_{\mathrm{O}}}{\mathrm{K}_{\mathrm{CO}} \mathrm{P}_{\mathrm{CO}}} \text {, i.e. an order of } 1 \text { in } \mathrm{O}_{2} \text { and of } 1 \text { in } \mathrm{CO} \text {. }
$$


Eqns 16 and 17 imply that $\mathrm{O}_{2}$ adsorption is not dissociative, which is coherent with the kinetic data. However $\mathrm{O}_{2}$ should be dissociated in further steps of the surface reaction. On ceria, new sites for $\mathrm{O}_{2}$ activation are created at the metal/support interface or in the vicinity of metal particles. As $\mathrm{CO}$ and $\mathrm{O}_{2}$ do not compete with the same sites, the rate equation becomes:

$$
\mathrm{r}=\mathrm{k} \frac{\mathrm{K}_{\mathrm{O}} \mathrm{P}_{\mathrm{O}}}{1+\mathrm{K}_{\mathrm{O}} \mathrm{P}_{\mathrm{O}}} \times \frac{\mathrm{K}_{\mathrm{CO}} \mathrm{P}_{\mathrm{CO}}}{1+\mathrm{K}_{\mathrm{CO}} \mathrm{P}_{\mathrm{CO}}}
$$

with orders between 0 and 1 for $\mathrm{CO}$ and $\mathrm{O}_{2}$, which is again coherent with data of Table 6. Numerous studies on CO oxidation have confirmed these conclusions, most of them differing by the intimate nature of the site for $\mathrm{O}_{2}$ activation as well as by the chemical state of the metals in the reaction. For $\mathrm{Pt} / \mathrm{CeO}_{2}-\mathrm{Al}_{2} \mathrm{O}_{3}$, Serre et al. $[55,56]$ have described a mixed site Pt-O-Ce, specially created in reducing conditions. The catalyst deactivates after a prolonged exposition in oxidative medium. The presence of specific sites for $\mathrm{O}_{2}$ adsorption on ceria was elegantly demonstrated by Johansson et al on $\mathrm{Pt} / \mathrm{CeOx}$ and $\mathrm{Pt} / \mathrm{SiO}_{2}$ catalysts prepared by electron beam lithography [57].On both samples, a kinetic bistability depending on the gas mixing ratio, $\beta={ }_{\mathrm{CO}} / \mathrm{P}_{\mathrm{CO}}+\mathrm{P}_{\mathrm{O}_{2}}$, can be observed. The bistable region is shifted considerably to much higher $\beta$ values on $\mathrm{Pt} / \mathrm{CeOx}$ than on $\mathrm{Pt} / \mathrm{SiO}_{2}$. This could be simulated in kinetic modeling by introducing an oxygen reactant supply via the $\mathrm{CeOx}$ support, which maintains a high $\mathrm{CO}$ conversion rate even in $\mathrm{CO}$ excess.

Similar rate expressions can be derived for propane oxidation. The first step would be the dehydrogenating adsorption of propane on metals giving a $\mathrm{CxHy}$ fragment (coverage: $\theta_{\mathrm{C}}$ ). Contrary to $\mathrm{CO}$, propane is much less strongly adsorbed on the metals than $\mathrm{O}_{2}$. The order 2 in $\mathrm{HC}$ and 1 in $\mathrm{O}_{2}$ on $\mathrm{Pt}$ could be explained by a surface reaction between $\mathrm{O}_{2 \text { ads }}$ and two CxHy species. On $\mathrm{Rh}$ and $\mathrm{Pd}, \mathrm{O}_{2}$ shows 
a moderate inhibitory effect much less significant than on Pt, kinetic orders being all comprised between 0 and 1 .

Clearly, OSC materials improve $\mathrm{CO}$ and to a lesser extent $\mathrm{HC}$ oxidation in $\mathrm{O}_{2}$ sub-stoichiometry. OSC materials can also promote reactions of steam with $\mathrm{CO}$ (water-gas shift) or $\mathrm{HC}$ (steam reforming) [58,59]. Both reactions produce hydrogen (Eq. 19 and 20):

$$
\begin{aligned}
& \mathrm{CO}+\mathrm{H}_{2} \mathrm{O} \rightarrow \mathrm{CO}_{2}+\mathrm{H}_{2} \\
& \mathrm{C}_{\mathrm{n}} \mathrm{H}_{\mathrm{m}}+\mathrm{nH}_{2} \mathrm{O} \rightarrow \mathrm{nCO}+\left(\mathrm{n}+\frac{\mathrm{m}}{2}\right) \mathrm{H}_{2}
\end{aligned}
$$

The promoter role of ceria in WGS reaction is demonstrated in Fig. 6.

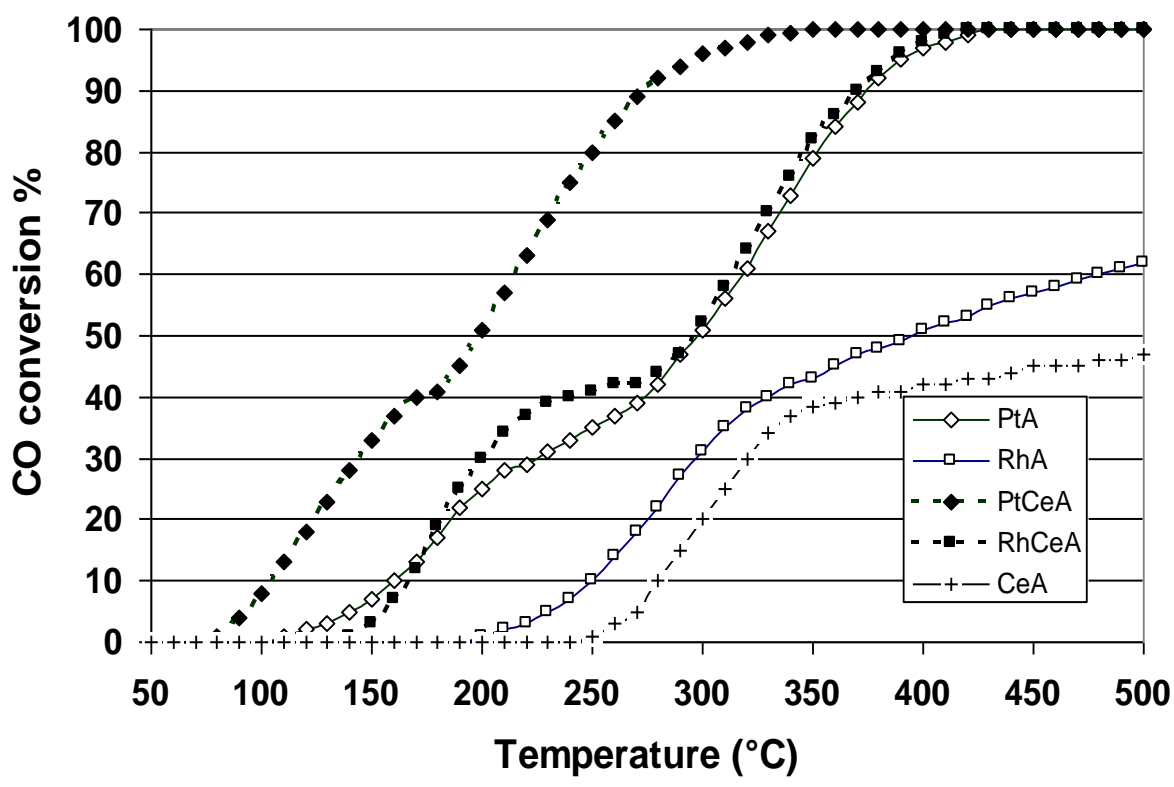

Fig. 6. Temperature-programmed reaction of $0.8 \% \mathrm{CO}$ in $0.16 \% \mathrm{O}_{2}+10 \% \mathrm{H}_{2} \mathrm{O}$ over $1 \% \mathrm{Pt}$ or $0.2 \% \mathrm{Rh}$ catalysts supported on alumina (A) or $12 \% \mathrm{CeO}_{2}-\mathrm{Al}_{2} \mathrm{O}_{3}(\mathrm{CeA})$. [58] 
Temperature-programmed conversion of $\mathrm{CO}$ was carried out in an oxygendeficient medium. The oxygen content was adjusted to obtain a maximum conversion of $40 \%$ by oxidation. The catalysts were $1 \% \mathrm{Pt}$ and $0.2 \% \mathrm{Rh}$ deposited over alumina (A) or $12 \% \mathrm{CeO}_{2}-\mathrm{Al}_{2} \mathrm{O}_{3}(\mathrm{CeA})$. The $\mathrm{CO}$ conversion is not limited by thermodynamic: it is higher than $99 \%$ over the entire range of temperature.

Two regions can be seen on the reaction profiles: the low-temperature domain corresponding to CO oxidation (limited at a $40 \%$ conversion) and the high temperature one where the $\mathrm{CO}$ having not been oxidized react with water (WGS domain). For every reaction, $\mathrm{Pt}$ is the best metal and ceria acts as a promoter. However, an exceptional increase of conversion can be observed in WGS when the metals are deposited on CeA.

Similar experiments were carried out using propane instead of CO as reducer [58]. It was shown that $\mathrm{Pt}$ was the best metal for $\mathrm{C}_{3} \mathrm{H}_{8}$ oxidation while $\mathrm{Rh}$ was the most active one in propane steam reforming. Introduction of $12 \% \mathrm{CeO}_{2}$ in the alumina support confirms that $\mathrm{CeO}_{2}$ rather inhibits $\mathrm{C}_{3} \mathrm{H}_{8}$ oxidation over $\mathrm{Pt}$ while it acts as a promoter on $\mathrm{Rh}$. In both cases, especially with $\mathrm{Rh}, \mathrm{CeO}_{2}$ increases the rate of propane steam reforming.

\subsection{Impact of OSC on NO conversion.}

The role of OSC materials in NO conversion is more complex. Most metals, specially $\mathrm{Rh}$, are able to decompose $\mathrm{NO}$ but this reaction is rapidly inhibited by $\mathrm{O}$ species resulting from this decomposition [60]. On $\mathrm{Rh}$, for instance, $\mathrm{Rh}-\mathrm{O}$ species are replaced by $\mathrm{Rh}-\mathrm{NO}^{+}$ones in which NO is no longer dissociated [61]. O species may react with adsorbed species of the reducer $(\mathrm{CO}, \mathrm{HC})$ to form $\mathrm{CO}_{2}$. The first role of the OSC materials could be to liberate metal sites by accepting $\mathrm{O}$ species. 
Indirect effects can also occur, with the $\mathrm{Ce}^{3+} / \mathrm{Ce}^{4+}$ redox system being able to regulate the metal state (zerovalent or ionic) during richness oscillations.

\section{Reduction of NO by CO}

The reaction may lead to $\mathrm{N}_{2}$ (Eq. 21) or $\mathrm{N}_{2} \mathrm{O}$ (Eq. 22).

$$
\begin{aligned}
& \mathrm{NO}+\mathrm{CO} \rightarrow 1 / 2 \mathrm{~N}_{2}+\mathrm{CO}_{2} \\
& 2 \mathrm{NO}+\mathrm{CO} \rightarrow \mathrm{N}_{2} \mathrm{O}+\mathrm{CO}_{2}
\end{aligned}
$$

For environmental reasons, reaction $21\left(\mathrm{NO} \rightarrow \mathrm{N}_{2}\right)$ should be promoted, $\mathrm{N}_{2} \mathrm{O}$ having a dramatic greenhouse gas effect. The different steps of reaction 23 have been investigated in detail, mainly by FTIR spectroscopy $[61,62,63]$. One of the possible intermediate is isocyanate. NCO species could be formed on the metal and migrate on the support, which may explain the large differences observed when $\mathrm{Rh}$ is supported on different oxides (alumina, silica, zirconia, ceriaalumina,...). However, the main step should be the dissociative adsorption of NO

$$
\mathrm{NO}_{\mathrm{g}}+2 * \rightarrow \mathrm{N} *+\mathrm{O} *
$$

This adsorption reaction has been extensively studied on most noble metals, specially on $\mathrm{Rh}$ by $\mathrm{NO}$ thermodesorption $[64,65,66]$. On $\mathrm{Rh} / \mathrm{ZrO}_{2}$ [65], it was shown that $\mathrm{N}_{2}$ left the surface from two separate features: a sharp $\beta_{1}$ peak at $170^{\circ} \mathrm{C}$ due to $\mathrm{N}_{2}$ desorption by reaction (24) and a broad peak $\left(\beta_{2}\right)$ between $180^{\circ} \mathrm{C}$ and $430^{\circ} \mathrm{C}$ corresponding to $\mathrm{N}_{2}$ recombination (Eq. 25):

$$
\begin{aligned}
& \mathrm{NO}_{\mathrm{g}}+\mathrm{N} * \rightarrow \mathrm{N}_{2 \mathrm{~g}}+\mathrm{O} * \\
& \mathrm{~N} *+\mathrm{N} * \rightarrow \mathrm{N}_{2 \mathrm{~g}}
\end{aligned}
$$

These reactions are very sensitive to particle size of rhodium. On big particles (10 $\mathrm{nm}$ ), both reaction can occur while, on the smallest ones (3-6 nm), only the recombination feature was observed. 
One of the first systematic studies of the NO reduction by $\mathrm{CO}$ was reported by Taylor and Kobylinski in 1974 [67]. The reaction was carried out in large excess of $\mathrm{CO}(0.5 \% \mathrm{NO}+2 \% \mathrm{CO})$, which favors the formation of $\mathrm{N}_{2}$. The light-off temperature $\mathrm{T}_{50}(50 \%$ conversion of $\mathrm{NO})$ allowed ranking the metals $\left(0.5 \% \mathrm{M} / \mathrm{Al}_{2} \mathrm{O}_{3}\right)$ by increased activity:

$$
\mathrm{Ru}, 205^{\circ} \mathrm{C}>\mathrm{Rh}, 296^{\circ} \mathrm{C}>\mathrm{Pd}, 431^{\circ} \mathrm{C}>\mathrm{Pt}, 471^{\circ} \mathrm{C}
$$

Except Ru (not usable in TWC because of the volatility of its oxide [68]), the most active metal is the rhodium. This has been largely confirmed by further studies so that Rh may be considered as a key-component of TWC for NO reduction [69,70]. As far as $\mathrm{Pd}$ is concerned, it seems that the active site is composed of $\mathrm{Pd}^{\mathrm{n}+}-\mathrm{Pd}^{0}$ pairs, which may explain the higher activity of $\mathrm{Pd}$ in $\mathrm{NO}+\mathrm{CO}+\mathrm{O}_{2}$ mixture $\left(\mathrm{T}_{50} \approx\right.$ $200^{\circ} \mathrm{C}$ ) [71]. A detailed kinetic study by Pande and Bell on Rh catalysts has evidenced a significant support effect [72]. The kinetic data were represented by a conventional power law expression:

$$
\mathrm{R}_{\mathrm{NO}}=\mathrm{k}_{\mathrm{NO}} \mathrm{P}_{\mathrm{NO}}^{\alpha} \mathrm{P}_{\mathrm{CO}}^{\beta}
$$

where $\mathrm{R}_{\mathrm{NO}}$ is the reaction rate per second and per metal site, $\mathrm{P}$, the pressure in atm, and $\mathrm{k}_{\mathrm{NO}}$ the kinetic constant in atm ${ }^{-(\alpha+\beta)} \mathrm{s}^{-1}$.

The main results are reported in Table 7.

Table 7: Kinetics of the $\mathrm{CO}+\mathrm{NO}$ reaction at $210^{\circ} \mathrm{C}$ over $\mathrm{Rh}$ catalysts. Gas composition is $1.3 \% \mathrm{NO}+3.9 \% \mathrm{CO}$ [72]

\begin{tabular}{ccccccc}
\hline Catalyst & $\begin{array}{c}\text { BET area Dispersion } \\
\mathrm{m}^{2} \mathrm{~g}^{-1}\end{array}$ & $\begin{array}{c}\text { Order } \\
/ \mathrm{NO}\end{array}$ & $\begin{array}{c}\text { Order } \\
/ \mathrm{CO}\end{array}$ & $\begin{array}{c}\mathrm{Ea} \\
\mathrm{kJ} \mathrm{mol}^{-1}\end{array}$ & $\begin{array}{c}\mathrm{k}_{\mathrm{NO}} \\
10^{-3}\end{array}$ \\
\hline $4.6 \% \mathrm{Rh} / \mathrm{SiO}_{2}$ & 250 & 55 & -0.2 & +0.1 & 140 & 4.30 \\
\hline $4.2 \% \mathrm{Rh} / \mathrm{Al}_{2} \mathrm{O}_{3}$ & 175 & 64 & -0.4 & $\sim 0$ & 101 & 0.82 \\
\hline $4.6 \% \mathrm{Rh} / \mathrm{MgO}$ & 100 & 46 & -0.2 & +0.1 & 108 & 2.92 \\
\hline $4.3 \% \mathrm{Rh} / \mathrm{TiO}_{2}$ & 50 & 26 & +0.1 & -0.2 & 82 & 7.75 \\
\hline $4.2 \% \mathrm{Rh} / \mathrm{La}_{2} \mathrm{O}_{3}$ & 14 & 10 & -0.2 & $\sim 0$ & 126 & 4.75 \\
\hline
\end{tabular}


The different catalysts may be ranked according to their relative activity:

$$
\mathrm{TiO}_{2}, 9.5>\mathrm{La}_{2} \mathrm{O}_{3}, 5.8>\mathrm{SiO}_{2}, 5.2>\mathrm{MgO}, 3.6>\mathrm{Al}_{2} \mathrm{O}_{3}, 1
$$

Between 100 and $200^{\circ} \mathrm{C}$, the selectivity to $\mathrm{N}_{2} \mathrm{O}$ is very high $(70-85 \%)$ and decreases with the temperature in accordance with most of the studies on the reduction of $\mathrm{NO}$ by $\mathrm{CO}$.

The kinetics of this reaction $\left(1.5 \% \mathrm{NO}+3 \% \mathrm{CO}, 200^{\circ} \mathrm{C}\right)$ on a $1 \% \mathrm{Rh} / \mathrm{SiO}_{2}$ catalyst promoted by Mo, Ce and $\mathrm{Nb}$ (1 to $10 \mathrm{wt}-\%)$ was studied by Hecker et al. [73]. A significant particle size effect was observed: the biggest particles of $\mathrm{Rh}$ are the most active per Rh site (Fig. 7). On silica, the promoter effects are mainly due to particle size effects: certain promoters, especially ceria being able to stabilize $\mathrm{Rh}$ particles. The presence of Mo tends to slow down the reaction so that Mo appears as an inhibitor of the reaction. Kinetic parameters obtained by Hecker et al. are close to those reported by Pande and Bell: orders slightly negative in NO ( -0.2 to -0.5 , exceptionally -1.2 for $\mathrm{Mo}$ ) and orders nil or slightly positive with respect to $\mathrm{CO}(0$ to +0.4$)$; activation energies between 117 and $139 \mathrm{~kJ} \mathrm{~mol}^{-1}$.

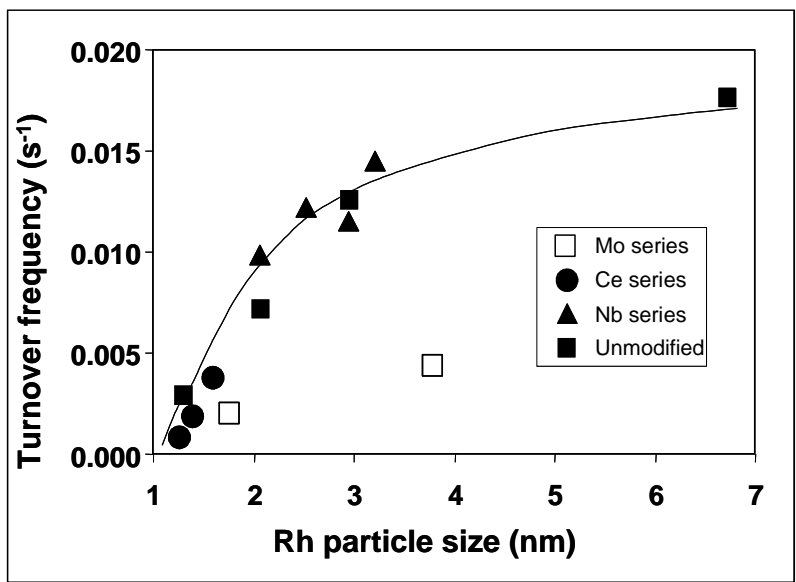

Fig. 7. Effect of the dispersion of $\mathrm{Rh}$ on the $\mathrm{NO}$ reduction by $\mathrm{CO}$ at $200^{\circ} \mathrm{C}$ over promoted $\mathrm{Rh} / \mathrm{SiO}_{2}$ catalysts $(1.5 \% \mathrm{NO}+3 \% \mathrm{CO})$ [73]. 
The reduction of $\mathrm{NO}$ by $\mathrm{CO}$ was investigated in detail by $\mathrm{Oh}$ et al. in closer conditions than those encountered in automotive converters: weaker $\mathrm{NO}$ and $\mathrm{CO}$ concentrations, close to the stoichiometry, more realistic metal content $(<1 \%)$ $[74,75]$. The main conclusions of Oh's works are:

- the high sensitivity of the reaction to particle size of $\mathrm{Rh}$ is confirmed: at $230^{\circ} \mathrm{C}$, in a mixture of $0.5 \% \mathrm{NO}+1 \% \mathrm{CO}$, the turnover frequency increases from $0.017 \mathrm{~s}^{-1}$ for a highly dispersed catalyst to $0.74 \mathrm{~s}^{-1}$ for a catalyst dispersed at $1.7 \%$, the activity per metal site on unsupported Rh catalysts being still much higher.

- ceria remarkably increases the activity of $\mathrm{Rh} / \mathrm{Al}_{2} \mathrm{O}_{3}: 2$ to 9 wt- $\% \mathrm{CeO}_{2}$ added to a $0.014 \% \mathrm{Rh} / \mathrm{Al}_{2} \mathrm{O}_{3}$ catalyst increases its activity by a factor 5 by $250^{\circ} \mathrm{C}$. However, ceria decreases the activation energy $\left(120 \mathrm{~kJ} \mathrm{~mol}^{-1}\right.$ on $\mathrm{Rh} / \mathrm{Al}_{2} \mathrm{O}_{3}$ : instead of 80 on $\mathrm{Rh} / \mathrm{CeO}_{2}-\mathrm{Al}_{2} \mathrm{O}_{3}$ ) so that the two catalysts have nearly the same activity around $300-310^{\circ} \mathrm{C}$.

- the reaction $\mathrm{CO}+\mathrm{NO}$ may be seen as an oxidation of $\mathrm{CO}$ by $\mathrm{NO}$ which competes with the oxidation of $\mathrm{CO}$ by $\mathrm{O}_{2}$. On $\mathrm{Rh}, \mathrm{CO}$ oxidation by dioxygen is almost two orders of magnitude faster than $\mathrm{CO}$ oxidation by NO. Nevertheless, if the three reactants are present together, the rate of $\mathrm{CO}$ oxidation by $\mathrm{O}_{2}$ dramatically decreases while that of $\mathrm{CO}$ by $\mathrm{NO}$ increases. As a consequence, both reactions occur practically at the same rate [76].

Most of the kinetic observations can be interpreted as follows:

- the key-step is the NO decomposition (Eq. 23): the global reaction rate depends for a great part of the rate of this step.

- at low temperature, $\mathrm{N}_{2}$ is mainly formed by the reaction of $\mathrm{NO}_{\mathrm{g}}$ with adsorbed $\mathrm{N}^{*}$ species (Eq. 24) or by the same reaction with adsorbed NO (Eq. 27):

$$
\mathrm{NO} *+\mathrm{N} * \rightarrow \mathrm{N}_{2}+\mathrm{O} *+*
$$

while $\mathrm{N}_{2} \mathrm{O}$ is formed by a similar reaction (Eq. 28): 


$$
\mathrm{NO} *+\mathrm{N} * \rightarrow \mathrm{N}_{2} \mathrm{O} *+*
$$

At high temperature, $\mathrm{NO}$ is almost totally dissociated: $\mathrm{N}_{2} \mathrm{O}$ cannot then be formed and $\mathrm{N}_{2}$ stems essentially from recombination of adsorbed $\mathrm{N}^{*}$ species (Eq. 25). The selectivity to $\mathrm{N}_{2}$ increases with the temperature and virtually reaches $100 \%$ around $300^{\circ} \mathrm{C}$ (Fig. 8).

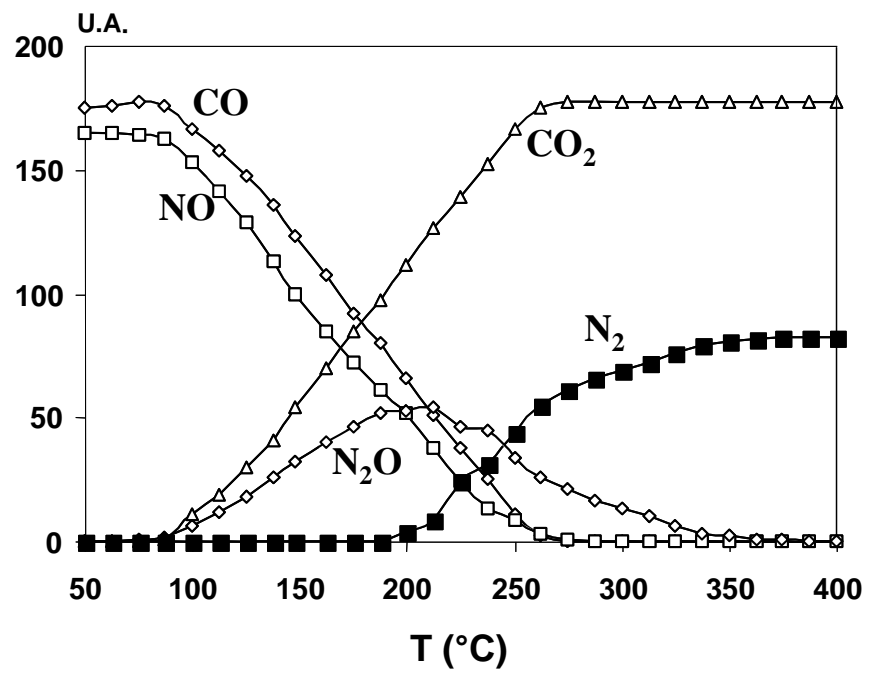

Fig. 8. Temperature-programmed reaction of $\mathrm{CO}(1 \%)+\mathrm{NO}(1 \%)$ over a preoxidized $0.2 \% \mathrm{Rh} / \mathrm{CeO}_{2}-\mathrm{Al}_{2} \mathrm{O}_{3}$ catalyst [77]

The chemical state of the metal can play a decisive role on the reaction mechanism. In TWC, Rh is thought to remain in the zero valent state, which favors NO dissociation [78,79]. However, the role of the OSC materials is complex and it is not inert with respect to NO activation. Ranga Rao et al. [80] showed that, when bulk oxygen vacancies are formed in a reduced $\mathrm{Ce}_{0.6} \mathrm{Zr}_{0.4} \mathrm{O}_{2}$ solid solution, $\mathrm{NO}$ was efficiently decomposed on the support to give $\mathrm{N}_{2} \mathrm{O}$ and $\mathrm{N}_{2}$. Further studies by the same group using different $\mathrm{Ce}_{\mathrm{x}} \mathrm{Zr}_{1-\mathrm{x}} \mathrm{O}_{2}$ composition and different metals confirmed 
this prominent property of supports containing reduced ceria $[81,82]$. Selected results of these studies are reported in Table 8.

A significant increase of activity can be observed on $\mathrm{Rh}$ catalysts supported on reducible oxides. Activity exaltation is severely annihilated when the catalysts are treated in the reaction mixture. Nevertheless, the presence of chlorine largely upset the results: $\mathrm{Cl}$ probably slows down the reduction of the support, particularly in the $\mathrm{CO}+\mathrm{NO}$ mixture.

By surface science techniques, Mullins and Overbury showed that the presence of reduced ceria might create new active sites for NO dissociation [83]. The degree of decomposition is increased and the onset temperature for decomposition is reduced when $\mathrm{Rh}$ is supported on reduced ceria $\left(\mathrm{Rh} / \mathrm{CeO}_{\mathrm{x}}\right)$ compared to $\mathrm{Rh}$ on oxidized ceria $\left(\mathrm{Rh} / \mathrm{CeO}_{2}\right) \mathrm{NO}$ dissociation being self-inhibiting.

Table 8: Effect of the reducing pretreatment of $0.5 \% \mathrm{Rh}$ catalysts on the $\mathrm{NO}+\mathrm{CO}$ reaction rate $(1 \% \mathrm{NO}+1 \% \mathrm{CO})[81,82]$.

\begin{tabular}{lccc}
\hline Support & $\begin{array}{c}\mathrm{Rh} \\
\text { precursor }\end{array}$ & $\begin{array}{c}\text { Reaction rate at } 200^{\circ} \mathrm{C} \\
\text { after pretreatment in } \\
\mathrm{H}_{2}, \text { for } 2 \mathrm{~h} \text { at } 200^{\circ} \mathrm{C} \\
\left(\mathrm{mole} \mathrm{NO} \mathrm{g}^{-1} \mathrm{~s}^{-1} \times 10^{9}\right)\end{array}$ & $\begin{array}{c}\text { Reaction rate at } 200^{\circ} \mathrm{C} \text { after } \\
\text { pretreatment in } \mathrm{CO}+\mathrm{NO} \\
\text { from } 200 \text { to } 500^{\circ} \mathrm{C} \\
\left(\text { mole } \mathrm{NO} \mathrm{g}^{-1} \mathrm{~s}^{-1} \times 10^{9}\right)\end{array}$ \\
\hline $\mathrm{Al}_{2} \mathrm{O}_{3}$ & Chloride & 70 & 32 \\
\hline $\mathrm{Ce}_{0.4} \mathrm{Zr}_{0.6} \mathrm{O}_{2}$ & Chloride & 331 & 90 \\
\hline $\mathrm{Ce}_{0.6} \mathrm{Zr}_{0.4} \mathrm{O}_{2}$ & Chloride & 336 & 46 \\
\hline $\mathrm{CeO}_{2}$ & Chloride & 1120 & 83 \\
\hline $\mathrm{Ce}_{0.6} \mathrm{Zr}_{0.4} \mathrm{O}_{2}$ & Nitrate & $1630^{\mathrm{a}}$ & $1590^{\mathrm{a}}$ \\
\hline
\end{tabular}

${ }^{a}$ Reaction rate at $160^{\circ} \mathrm{C}$

The promotion by reduced ceria could be due to a spill-over phenomenon of $\mathrm{O}$ species from metal to support. In fact, this is not sufficient to explain all the results of Mullins and Overbury: an exposure of the $\mathrm{Rh} / \mathrm{CeOx}$ surface to water leads to a 
re-oxidation accompanied by a hydroxylation of the support while the metal surface is left unchanged. In fact, it seems that preferential orientation of Rh surface on reduced ceria may also explain the specific role of $\mathrm{CeOx}$ surface. This is consistent with the fact that NO dissociation occurs at lower temperatures on $\mathrm{Rh}$ (110) and on $\mathrm{Rh}(100)$ than on $\mathrm{Rh}(111)$ [84,85].

However, reduced ceria is able, alone, to dissociate NO. Martinez-Arias et al. [86] have first investigated by EPR and FTIR spectroscopies NO reaction on ceria pre-outgassed at different temperatures and showed the role of superoxides differentially coordinated in the formation of hyponitrites species further decomposed into $\mathrm{N}_{2} \mathrm{O}$. Later Haneda et al. [87] have demonstrated that reduced ceria and reduced praseodymium oxide dissociate $\mathrm{NO}$ even though the presence of a noble metal (Pt) significantly increases the formation of $\mathrm{N}_{2}$ or $\mathrm{N}_{2} \mathrm{O}$. The main results of this study are summarized in Table 9.

Lanthanum and samarium shows virtually no NO dissociation activity even in the presence of Pt. These supports are not reducible and have no OSC property. The intrinsic NO dissociation activity of platinum is very weak, probably in reason of the low metal dispersion. The behavior of terbium oxide is more surprising: although it is reducible in $\mathrm{H}_{2}$, it is unable dissociating $\mathrm{NO}$ except in the presence of Pt.

The specific role of OSC materials in NO activation and NO dissociation has largely been confirmed by many authors over Pt-Rh $[88,89]$ and Pd catalysts [90,91] or even over bare OSC oxides [92]. By EPR, Lecomte et al. [88] evidence the presence of $\mathrm{O}_{2}^{-}$superoxide species over a $\mathrm{Pt}-\mathrm{Rh} / \mathrm{Al}_{2} \mathrm{O}_{3}$ catalyst modified by ceria. The formation of these species could be closely related to the performance of the $\mathrm{Pt}-\mathrm{Rh} / \mathrm{CeO}_{2}-\mathrm{Al}_{2} \mathrm{O}_{3}$ catalyst in $\mathrm{CO}+\mathrm{NO}$ reaction. 
Table 9: NO dissociation over reduced rare-earth oxides and over 1\%Pt catalysts deposited on these oxides. Prior to NO dissociation (970 ppm NO), the samples are reduced for $1 \mathrm{~h}$ in $\mathrm{H}_{2}$ at $500^{\circ} \mathrm{C}$ [87].

\begin{tabular}{|c|c|c|c|c|}
\hline \multirow[b]{2}{*}{ RE oxide } & \multirow[t]{2}{*}{$\begin{array}{c}\text { BET area } \\
\mathrm{m}^{2} \mathrm{~g}^{-1}\end{array}$} & \multirow{2}{*}{$\begin{array}{c}\mathrm{H}_{2} \mathrm{TPR} \\
\left(25-500^{\circ} \mathrm{C}\right) \\
\mu \mathrm{mol} \mathrm{H} \mathrm{g}^{-1}\end{array}$} & \multicolumn{2}{|c|}{$\begin{array}{c}\mathrm{N}_{2}\left(\mathrm{~N}_{2} \mathrm{O}\right) \text { formed } \\
\mathrm{mmol} \mathrm{g}^{-1}\end{array}$} \\
\hline & & & at $200^{\circ} \mathrm{C}$ & at $400^{\circ} \mathrm{C}$ \\
\hline $\mathrm{La}_{2} \mathrm{O}_{3}$ & 7.5 & 2.5 & & $0.0(0.0)$ \\
\hline $\mathrm{CeO}_{2}$ & 55 & 75 & & $14.7(2.6)$ \\
\hline $\mathrm{Pr}_{6} \mathrm{O}_{11}$ & 9.5 & 773 & & $19.6(4.6)$ \\
\hline $\mathrm{Sm}_{2} \mathrm{O}_{3}$ & 8.0 & 1.5 & & $0.0(0.0)$ \\
\hline $\mathrm{Tb}_{4} \mathrm{O}_{7}$ & 22 & 1008 & & $0.0(0.0)$ \\
\hline \multicolumn{5}{|c|}{ Pt/RE oxides } \\
\hline $\mathrm{Pt} / \mathrm{La}_{2} \mathrm{O}_{3}$ & & 17 & $0.0(0.0)$ & $1.8(0.2)$ \\
\hline $\mathrm{Pt} / \mathrm{CeO}_{2}$ & & 271 & $50.0(1.1)$ & $52.3(0.0)$ \\
\hline $\mathrm{Pt} / \mathrm{Pr}_{6} \mathrm{O}_{11}$ & & 1823 & $225(226)$ & $431(10.5)$ \\
\hline $\mathrm{Pt} / \mathrm{Sm}_{2} \mathrm{O}_{3}$ & & 41 & $0.0(0.0)$ & $5.5(0.2)$ \\
\hline $\mathrm{Pt} / \mathrm{Tb}_{4} \mathrm{O}_{7}$ & & 1356 & $27.2(8.1)$ & $248(0.0)$ \\
\hline
\end{tabular}

When the ceria-containing catalyst is pre-reduced before reaction, a typical temperature-programmed reaction profile can be observed (Fig. 9). While prereducing the catalyst has virtually no effect on $\mathrm{Pt}-\mathrm{Rh} / \mathrm{Al}_{2} \mathrm{O}_{3}$, a significant activity peak can be observed at low temperature on the ceria-based catalyst. This peak disappears upon calcination and a profile like that of Fig. 9 can then be recorded. It is not systematically recorded in bench tests with complex synthetic mixtures [93]. 


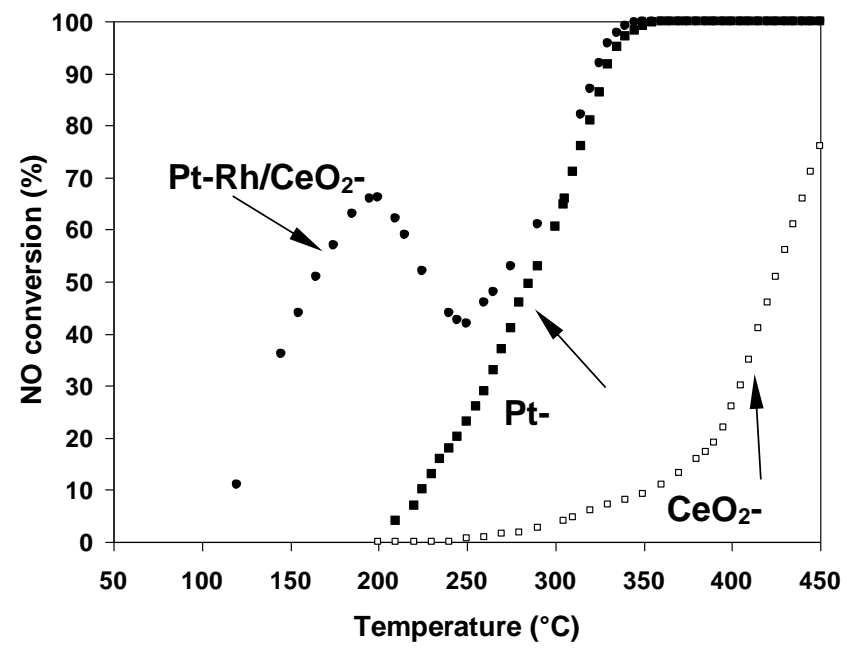

Fig. 9 Effect of ceria on the NO reduction by $\mathrm{CO}$ (Gas composition: $0.5 \% \mathrm{NO}+0.5 \% \mathrm{CO}, 25000 \mathrm{~h}^{-1}$ ). After Ref. 88 .

The behavior of $\mathrm{CeO}_{2}-\mathrm{Al}_{2} \mathrm{O}_{3}$ support is rather general and can be observed with other ceria-containing catalysts such as $\mathrm{Rh} / \mathrm{CeO}_{2}-\mathrm{ZrO}_{2}$ catalysts $[81,82]$ or $\mathrm{Pd} /$ $\mathrm{CeO}_{2}-\mathrm{ZrO}_{2}$ [94]. It has also been shown that pre-reduced ceria-zirconia supports present a noticeable activity in $\mathrm{NO}+\mathrm{CO}$ in the absence of metal. This activity totally disappears when the support is calcined [89].

Reduction of $\mathrm{NO}$ by $\mathrm{H}_{2}$ and hydrocarbons

Compared to $\mathrm{CO}$, these reactions were much less studied over TW catalysts. Kobylinski and Taylor [67] have compared the NO reduction by $\mathrm{CO}$ and by $\mathrm{H}_{2}$. Their main results are summarized in Tables 10 (light-off activity) and 11 (selectivity). 
Table 10: Temperatures $\left(\mathrm{T}^{\circ} \mathrm{C}\right)$ for $50 \% \mathrm{NO}$ conversion as a function of the reducing agent. Catalysts: $0.5 \%$ metal on alumina. Space velocity: $24000 \mathrm{~h}^{-1}$.

\begin{tabular}{cccc}
\hline Catalyst & $\mathrm{NO}+\mathrm{H}_{2}$ & $\mathrm{NO}+\mathrm{CO}$ & $\mathrm{NO}+\mathrm{CO}+\mathrm{H}_{2}$ \\
\hline $\mathrm{Pt}$ & 121 & 471 & 398 \\
$\mathrm{Pd}$ & 106 & 431 & 330 \\
$\mathrm{Rh}$ & 163 & 296 & 275 \\
$\mathrm{Ru}$ & 237 & 205 & 210 \\
\hline
\end{tabular}

Table 11: Product selectivity (\% NO converted in $\mathrm{N}_{2}$ and $\mathrm{NH}_{3}$ ) and reaction selectivity ( $\% \mathrm{NO}$ converted by $\mathrm{NO}+\mathrm{CO}$ and $\left.\mathrm{NO}+\mathrm{H}_{2}\right)$. Gas composition $1.5 \% \mathrm{NO}$ $+4.5 \% \mathrm{CO}+4.5 \% \mathrm{H}_{2}$.

\begin{tabular}{|c|c|c|c|c|c|c|c|}
\hline \multirow[t]{2}{*}{ Catalyst } & \multirow{2}{*}{$\begin{array}{c}\mathrm{T} \\
\left({ }^{\circ} \mathrm{C}\right)\end{array}$} & \multirow{2}{*}{$\begin{array}{c}\text { NO conv. } \\
\%\end{array}$} & \multicolumn{4}{|c|}{ Selectivity } & \multirow{2}{*}{$\begin{array}{c}\% \mathrm{~N}_{2} \text { from } \\
\mathrm{NO}+\mathrm{CO}\end{array}$} \\
\hline & & & $\mathrm{NO} \rightarrow \mathrm{N}_{2}$ & $\mathrm{NO} \rightarrow \mathrm{NH}_{3}$ & $\mathrm{NO}+\mathrm{CO}$ & $\widehat{\mathrm{NO}+\mathrm{H}_{2}}$ & \\
\hline $\mathrm{Pt}$ & 515 & 94 & 23 & 77 & 8 & 92 & 40 \\
\hline $\mathrm{Pd}$ & 515 & 94 & 26 & 74 & 9 & 91 & 38 \\
\hline $\mathrm{Rh}$ & 482 & 100 & 67 & 33 & 20 & 80 & 29 \\
\hline $\mathrm{Ru}$ & 432 & 100 & 92 & 8 & 29 & 71 & 31 \\
\hline
\end{tabular}

$\mathrm{Pt}$ and $\mathrm{Pd}$ are by far the most active metals in $\mathrm{NO}$ reduction by $\mathrm{H}_{2}$ while $\mathrm{Rh}$ and $\mathrm{Ru}$ present the highest activity in NO reduction by $\mathrm{CO}$. However, when the two reducers are injected together (last column), CO tends to impose its behavior in $\mathrm{NO}$ reduction. This is due to a strong adsorption of $\mathrm{CO}$, which inhibits the reduction by $\mathrm{H}_{2}$.

Although $\mathrm{CO}$ seemed to inhibit the reduction by $\mathrm{H}_{2}$, this reducer still maintains a very significant activity. The $\mathrm{CO}$ inhibition is largely compensated by the high temperature of working. Interestingly, Table 11 confirms the good selectivity of $\mathrm{Rh}$ (and $\mathrm{Ru}$ ) to $\mathrm{N}_{2}$ while Pt and Pd lead to a significant formation of ammonia. Maunula et al. [95] have confirmed the superiority of Pt over $\mathrm{Rh}$ in the reduction 
of $\mathrm{NO}$ by $\mathrm{H}_{2}$. They also found that $\mathrm{N}_{2} \mathrm{O}$ would be an intermediate in the formation of $\mathrm{N}_{2}$.

Relatively few studies were devoted to the reduction of NO by $\mathrm{HC}$ in TW conditions. Platinum seems to be a good reducer of NO by light alkanes, specially the methane [96]:

$$
\mathrm{CH}_{4}+4 \mathrm{NO} \rightarrow 2 \mathrm{~N}_{2}+\mathrm{CO}_{2}+2 \mathrm{H}_{2} \mathrm{O}
$$

However, some contradictory results were obtained in several studies. For instance, in the $\mathrm{CH}_{4}-\mathrm{NO}$ reaction, some authors have reported that $\mathrm{N}_{2} \mathrm{O}$ was the primary product [96] while others found that ammonia was first produced [97]. The presence of water can play a decisive role since $\mathrm{H}_{2} \mathrm{O}$ allows generating $\mathrm{H}_{2}$ by WGS or steam reforming [59]. Olefins generally show a higher activity than alkanes: propene for instance has been found more reactive than propane. Some exceptions should be quoted, ethylene having been found less reactive than $\mathrm{CH}_{4}$ in NO reduction at stoichiometry [98].

The role of ceria is practically not evoked in these previous studies. More recently, Pérez-Hernández et al. have compared the catalytic behavior of $\mathrm{Pt} / \mathrm{ZrO}{ }_{2}, \mathrm{Pt} / \mathrm{CeO}_{2}$ and $\mathrm{Pt} / \mathrm{CeO}_{2}-\mathrm{ZrO}_{2}$ in $\mathrm{NO}$ reduction by $\mathrm{CH}_{4}$ or $\mathrm{CO}$ [99]. All the catalysts were found more active and more selective to $\mathrm{N}_{2}$ in $\mathrm{NO}$ reduction by $\mathrm{CH}_{4}$. However the cerium content plays a decisive role in decreasing the differences of NO light-off activity between $\mathrm{CH}_{4}+\mathrm{NO}$ and $\mathrm{CO}+\mathrm{NO}$. Rather different results were obtained by Bera et al. [100] who found $\mathrm{Pt} / \mathrm{CeO}_{2}$ more active in $\mathrm{CO}+\mathrm{NO}(100 \%$ conversion achieved at $\left.270^{\circ} \mathrm{C}\right)$ than in $\mathrm{NO}+\mathrm{CH}_{4}\left(100 \%\right.$ conversion at $\left.350^{\circ} \mathrm{C}\right)$. However, the superiority of the ceria support with respect to alumina in NO reduction was demonstrated both for Pt and Pd catalysts. As said before, ceria may also modify the catalyst behavior by increasing the $\mathrm{H}_{2}$ content in rich conditions, which may induce a higher capacity of the catalyst to reduce NO. 
A close parallelism could be established between the OSC of aged catalysts and their light-off activity in CO, HC and NOx conversion [101]. Different evolutions of both the OSC and the catalytic activity were observed depending on the method of ageing (laboratory ageing or engine bench ageing) and on the type of catalyst $\left(\mathrm{PtRh} / \mathrm{CeO}_{2}-\mathrm{Al}_{2} \mathrm{O}_{3}\right.$ or $\mathrm{PdRh} / \mathrm{CeO}_{2}-\mathrm{Al}_{2} \mathrm{O}_{3}$ ). In every case, the conversion of $\mathrm{NOx}$ is the most sensitive to catalyst ageing. This has been confirmed by Muraki and Zhang who compared $\mathrm{CO}, \mathrm{HC}$ and $\mathrm{NO}$ conversions over aged $\mathrm{Rh}$ catalysts supported on ceria and ceria-zirconia [70]: the conversions were significantly higher over ceria-zirconia supported Rh catalysts, much more stable than those supported on pure ceria. Ageing the catalyst, especially in rich/lean oscillation, may also leads to heterogeneity in the Ce local concentration. Finally, possible migration of $\mathrm{Ce}^{4+}$ ions was observed by Fan et al. in $\mathrm{Pt} / \mathrm{Ce}_{0.67} \mathrm{Zr}_{0.33} \mathrm{O}_{2}$ catalyst in rich/lean oscillations. Cerium ions may then decorate Pt particles and deeply modified their behavior in NO reduction [102].

\section{Impact of OSC materials in lean-burn and Diesel catalysis}

The impact of oxygen storage in DeNOx catalysis in $\mathrm{O}_{2}$ excess is more complex and strongly depends on the process used for NOx reduction. The impact of OSC materials will be examined on two processes: the selective reduction by $\mathrm{HC}$ (HC$\mathrm{SCR}$ ) and the NOx-trap process.

\subsection{Impact of OSC materials in HC-SCR}

In the 90's, most investigations were devoted to passive DeNOx, i.e. NOx reduction by the $\mathrm{HC}$ present in the exhaust gas. Even in lean conditions, there remains $\mathrm{Ce}^{3+}$ cations and oxygen vacancies which may participate in $\mathrm{NO}$ or $\mathrm{HC}$ 
activation. In 2000, Djega-Mariadassou et al. [78] proposed the following model for $\mathrm{NO}$ adsorption in $\mathrm{Rh} / \mathrm{CeO}_{2}$ where $\mathrm{Rh}$ is partially oxidized while there remain reduced sites of ceria on the support (Fig. 10)

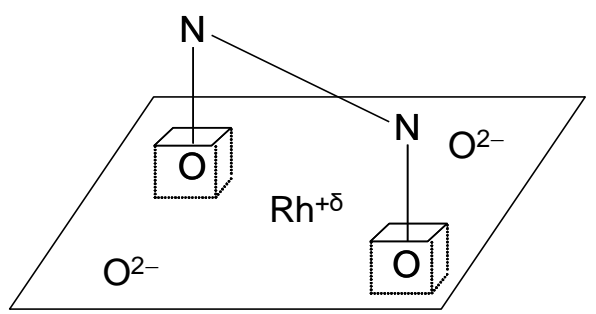

Fig. 10. Model of adsorption site for $\mathrm{NO}$ in the presence of $\mathrm{O}_{2}$ (adapted from Ref. 78). The cubes represent oxygen vacancies. $\mathrm{Rh}^{+\delta}$ would be the site for $\mathrm{HC}$ (or CO) activation.

However, there are also evidences that $\mathrm{Ce}^{3+}$ cations could participate in $\mathrm{NO}$ activation and dissociation $[86,103,104]$. The model of Fig. 10 was later modified to take into account this possibility [105]. It seems that the behavior of $\mathrm{Pd} / \mathrm{CeO}_{2}$ $\mathrm{ZrO}_{2}$ can be explained by similar models of $\mathrm{NO}$ and $\mathrm{HC}$ activation [106]: $\mathrm{NO}$ would be adsorbed on reduced sites of ceria-zirconia while the hydrocarbon (propylene in this study) would be partially oxidized into $\mathrm{C}_{\mathrm{x}} \mathrm{H}_{\mathrm{y}} \mathrm{O}_{\mathrm{z}}$ intermediates over PdOx sites. For the reduction of NO in oxygen excess, it seems however that conventional catalysts, even doped with OSC materials, cannot adsorb the HC's to reduce the NOx efficiently. Engineers of Toyota have proposed a system composed of a dual bed in which the conventional Pt catalyst is mixed with different zeolites [107]. A relatively close contact between Pt and the zeolite which stores the HC's is required but the advantage of this technique is that the zeolite as well as the presence of an OSC materials prevent the poisoning of Pt by heavy HC's. Some experiments were carried out with Pt in the zeolite but the most interesting system would the multi-component catalyst schematized in Fig. 11. 


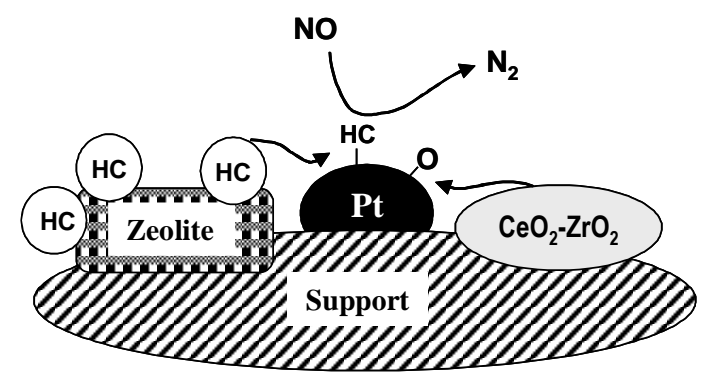

Fig. 11. Cooperative effect of an OSC component and a zeolite in SCR-HC of NO in $\mathrm{O}_{2}$ excess.

The idea to insert an OSC component such as Ce ions in zeolite has received much attention. Cordoba et al [108] have shown that H-ZSM5 promoted both by $\mathrm{Ce}$ and Pd has excellent properties in lean-DeNOx by dodecane (Fig. 12). As in the previous example (Fig. 11) the zeolite should help storing and probably transforming the dodecane molecule into highly reducing species. Thanks to their redox properties, Ce ions could adsorb NO and maintain Pd in the better chemical state to reduce NO.

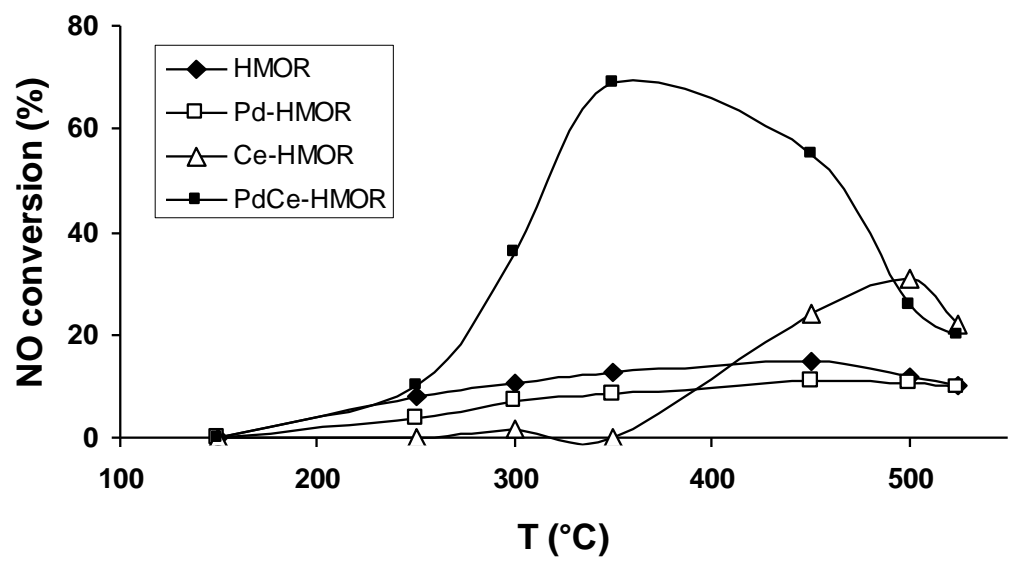

Fig. 12. Cooperative effect of $\mathrm{Pd}$ and $\mathrm{Ce}$ in lean-DeNOx by dodecane (900 ppm $\mathrm{NO}+100 \mathrm{ppm} \mathrm{NO} \mathrm{NO}_{2}+30 \mathrm{ppm} \mathrm{N} \mathrm{N}_{2} \mathrm{O}+400 \mathrm{ppm} \mathrm{C}_{12} \mathrm{H}_{26}+6 \% \mathrm{O}_{2}$ [108]. 
Very few studies were devoted to $\mathrm{NO}$ reduction by $\mathrm{H}_{2}$ in lean conditions because of the high reactivity of $\mathrm{H}_{2}$ with $\mathrm{O}_{2}$. Costa et al $[109,110]$ discovered a new low loaded Pt catalyst able to perform $\mathrm{H}_{2}$-DeNOx with a good selectivity. It consists of $0.1 \% \mathrm{Pt}$ supported on $\mathrm{La}_{0.5} \mathrm{Ce}_{0.5} \mathrm{MnO}_{3}$. This catalyst was found very active (74\% $\mathrm{NO}$ conversion at $140^{\circ} \mathrm{C}$ in a mixture $0.25 \% \mathrm{NO}, 1 \% \mathrm{H}_{2}, 5 \% \mathrm{O}_{2}, 5 \% \mathrm{H}_{2} \mathrm{O} / \mathrm{He}$, GHSV: $\left.80,000 \mathrm{~h}^{-1}\right)$ and more selective to $\mathrm{N}_{2}\left(87 \%\right.$ at $\left.140^{\circ} \mathrm{C}\right)$ than a conventional $0.1 \% \mathrm{Pt} /$ alumina catalyst [109]. By transient isotopic exchange reaction, Costa and Efstathiou showed that the interface metal/support played a significant role in NO reduction. Two kinds of active NOx species were evidenced: $\mathrm{M}-\mathrm{NO}_{2}{ }^{+}$located on the $\mathrm{La}_{0.5} \mathrm{Ce}_{0.5} \mathrm{MnO}_{3}$ support and $\mathrm{M}-\mathrm{O}-(\mathrm{NO})-\mathrm{O}-\mathrm{M}$ at the interface metal/support, while on a non-selective Pt catalyst, virtually all the active species are on Pt (Pt$\mathrm{NO}^{\delta+}$ or Pt-nitrate) [110].

\subsection{Impact of OSC materials on NOx-trap systems}

One of the most promising processes is the active DeNOx based on NOx-trap materials. It has been developed for lean-burn gasoline engines. Cerium compounds are thought to intervene in different steps of the whole process: (i) NO oxidation, (ii) NOx storage; (iii) Nitrate desorption and NOx reduction. Most probably, the main role of OSC materials is to accelerate $\mathrm{HC}$ partial oxidation during rich-spikes (giving $\mathrm{CO}$ and $\mathrm{H}_{2}$ as $\mathrm{NOx}$ reducers). However, this beneficial effect of OSC compounds competes with a detrimental reaction, i.e. the reduction of the OSC materials itself that may delay HC decomposition and thus NOx reduction [111]. Nakatsuji et al. [112], in cooperation with researchers of Isuzu, have studied the effect of OSC materials on simplified catalysts inasmuch as Rh was directly deposited on oxides known for their OSC properties (Ce, $\mathrm{Ce}-\mathrm{Zr}, \mathrm{Ce}-$ Pr, Ce-Nd-Pr, Ce-Gd-Zr oxides). These catalysts were submitted to periodic lean 
(55s)/rich (5s) excursions as in the conventional NOx-trap system. Compared to non-OSC supports, ceria allows maintaining a high DeNOx activity even in large $\mathrm{O}_{2}$ excess during the lean period (Fig. 13).

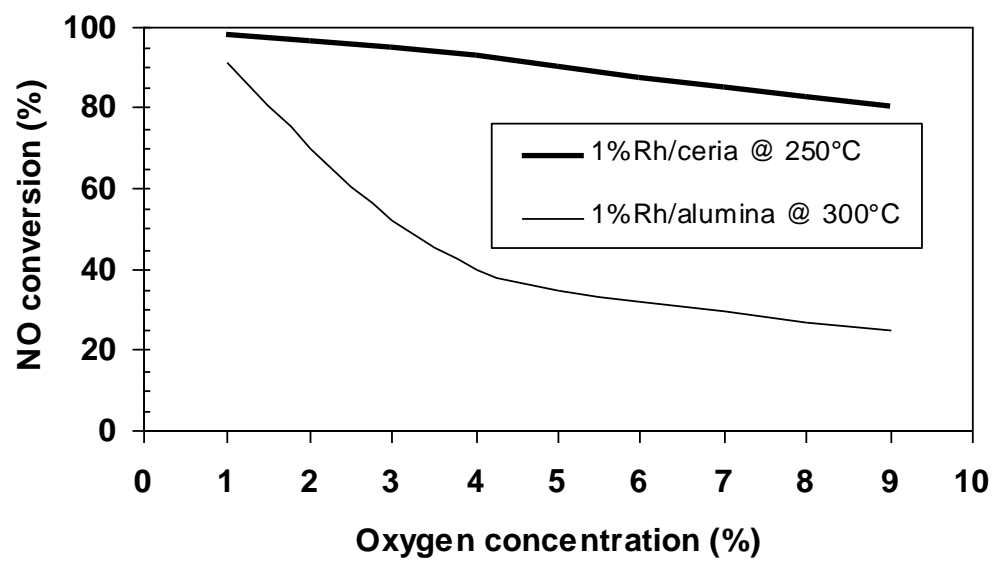

Fig. 13. Effect of $\mathrm{O}_{2}$ concentration over Rh-loaded catalysts at the temperature of their max. activity (lean/rich spans: 55/5s; 50,000 h $\mathrm{h}^{-1}$ ).

Even in absence of the classical Ba component, OSC materials may play a role in the NOx reduction using severely lean/rich conditions.

Most of other studies implying OSC materials were devoted to the chemical interaction between the NOx-trap materials $(\mathrm{Ba})$ and the OSC oxides. The order of introduction of the different functions (metal=Pd, OSC and NOx-trap) was studied by Kolli et al. [113]. Although the aim of this work was to study the catalysts in TWC conditions, some interesting results were obtained which may be generalized to other conditions. It was shown that the best catalysts consisted of Pd-Ba or Ba$\mathrm{Pd}$ deposited over $\mathrm{OSC}-\mathrm{Al}_{2} \mathrm{O}_{3}$ support, i.e. the OSC materials should be impregnated first. Although their catalyst was not optimized, Liotta et al. [114] have investigated a Pt-OSC/Ba- $\mathrm{Al}_{2} \mathrm{O}_{3}$ catalyst in NOx-trap conditions. Interestingly, they showed that Ba ions migrated through the OSC layer $(\mathrm{CeZrOx})$. 
This property could allow a better control of the Ba dispersion as well as an increased resistance to $\mathrm{SO}_{2}$ poisoning. However the presence of $\mathrm{Ba}$ is not essential for the NOx-trap when OSC material is used as support. Eberhardt et al. [115] and Philipp et al. [116] have compared the NOx trap behavior of $\mathrm{Ba} / \mathrm{Al}_{2} \mathrm{O}_{3}$ and $\mathrm{Ba} / \mathrm{CeO}_{2}$ materials. $\mathrm{Ba} / \mathrm{CeO}_{2}$ show higher NOx storage efficiency than $\mathrm{Ba} / \mathrm{Al}_{2} \mathrm{O}_{3}$ within the temperature range of $200-400^{\circ} \mathrm{C}$. No solid/solid reaction between $\mathrm{Ba}$ and ceria was observed below $780^{\circ} \mathrm{C}$ while $\mathrm{Ba}$ reacted at lower temperature with $\mathrm{Al}_{2} \mathrm{O}_{3}$ to form inactive $\mathrm{Ba}$ aluminate. In these previous studies, however, no noble metal was impregnated on the support, which may bias the results in real catalysts. Corbos et al. have compared the NOx storage capacities of $\mathrm{Pt} / \mathrm{CeZrOx}$ with a classical $\mathrm{Pt} / \mathrm{Ba} / \mathrm{Al}_{2} \mathrm{O}_{3}$ and with $\mathrm{Pt} / \mathrm{Ba} / \mathrm{CeZrOx}$. The values given in Table 12 show a better capacity for $\mathrm{Pt} / \mathrm{CeZrOx}$ at certain temperatures [117].

Table 12: NOx storage capacities $\left(\mu \mathrm{mol} . \mathrm{g}^{-1}\right)$ calculated for the first 100 seconds. The catalysts were stabilized at $700^{\circ} \mathrm{C}$ under $\mathrm{O}_{2}, \mathrm{H}_{2} \mathrm{O}, \mathrm{N}_{2}$; Storage mixture : 350 ppm NO, $10 \% \mathrm{O}_{2}, 10 \% \mathrm{H}_{2} \mathrm{O}, 10 \% \mathrm{CO}_{2}$ and $\mathrm{N}_{2}$. (Ref. 117)

NOx storage capacities $\left(\mu \mathrm{mol} . \mathrm{g}^{-1}\right)$

\begin{tabular}{lccc}
\hline Storage temperature $\left({ }^{\circ} \mathrm{C}\right)$ & 200 & 300 & 400 \\
\hline $\mathrm{Pt} / \mathrm{Ba} / \mathrm{Al}\left(129 \mathrm{~m}^{2} \cdot \mathrm{g}^{-1}\right)$ & 13.1 & 13.7 & 18.3 \\
\hline $\mathrm{Pt} / \mathrm{CeZr}\left(61 \mathrm{~m}^{2} \cdot \mathrm{g}^{-1}\right)$ & 17.1 & 14.6 & 15.0 \\
\hline $\mathrm{Pt} / \mathrm{Ba} / \mathrm{CeZr}\left(47 \mathrm{~m}^{2} \cdot \mathrm{g}^{-1}\right)$ & 9.4 & 11.8 & 23.3 \\
\hline
\end{tabular}

Similar results were obtained by Lin et al. [118] who investigated the effect of $\mathrm{La}$ and $\mathrm{Ce}$ on NOx storage properties of $\mathrm{Pt} / \mathrm{Ba}-\mathrm{Al}_{2} \mathrm{O}_{3}$. Substituting $\mathrm{La}$ for $\mathrm{Ce}$ increased the NOx storage capacity from $341 \mu \mathrm{mol} \mathrm{g}{ }^{-1}$ in $\mathrm{Pt}_{2.5} \mathrm{La}_{30.5} \mathrm{Ba}_{33.4} \mathrm{Al}_{100}$ to $1020 \mu \mathrm{mol} \mathrm{g}{ }^{-1}$ for the $\mathrm{Pt}_{2.5} \mathrm{Ce}_{30.5} \mathrm{Ba}_{33.4} \mathrm{Al}_{100}$ catalyst. 
Finally, unconventional OSC supports have also been investigated. Machida et al, for instance, studied a $\mathrm{Pd} / \mathrm{MnOx}-\mathrm{CeO}_{2}$ as $\mathrm{NOx}$-storage materials [119]. This catalyst was tested in lean/rich conditions using $\mathrm{H}_{2}$ as reducer with, however, an unusual period (9 min. lean $/ 3 \mathrm{~min}$. rich). The catalyst showed both excellent activity and selectivity (almost $100 \%$ to $\mathrm{N}_{2}$ ).

\section{References}

[1] H. S. Ghandi, A. G. Piken, M. Shelef, R. G. Deloch, SAE Paper 760201 (1976).

[2] H. C. Yao, Y. F. Yu Yao, J. Catal. 86 (1984) 254.

[3] E. C. Su, C. N. Montreuil, W. G. Rothschild, Appl. Catal. 17 (1985) 75.

[4] E. C. Su, W. G. Rothschild, J. Catal. 99 (1986) 506.

[5] B. Engler, E. Koberstein, P. Schubert, Appl. Catal. 48 (1989) 71.

[6] T. Miki, T. Ogawa, M. Haneda, N. Kakauta, A. Ueno, S. Tateishi, S. Matsuuta, M. Sato, J. Phys. Chem. 94 (1990) 6464.

[7] M. Ozawa, M. Kimura, A. Isogai, J. Alloys Comp. 193 (1993) 73.

[8] P. Fornasiero, R. Di Monte, G. Ranga Rao, J. Kašpar, S. Meriani, A. Trovarelli, M. Graziani, J. Catal. 151 (1995) 168.

[9] J. P. Cuif, G. Blanchard, O. Touret, A. Seigneurin, M. Marczi, E. Quéméré, SAE Paper Nr 970463 (1997).

[10] S. Rossignol, F. Gérard, D. Duprez, J. Mater. Chem. 9 (1999) 1615.

[11] E.S.J. Lox and B.H. Engler in "Environmental Catalysis". G. Ertl. Et al. eds. WileyVCH 1999, p. 1

[12] S. Kacimi, J. Barbier Jr, R. Taha, D. Duprez, Catal. Lett. 22 (1993) 343.

[13] C. E. Hori, H. Permana, K. Y. Simon Ng, A. Brenner, K. More, K. M. Rahmoeller, D. Belton, Appl. Catal. B, 16 (1998) 105.

[14] Y. Madier, C. Descorme, A. M. LeGovic, D. Duprez, J. Phys. Chem. B 103 (1999) 10999.

[15] S. Bedrane, C. Descorme, D. Duprez, Catal. Today, 73 (2002) 233.

[16] E. Rohart, O. Larcher, C. Hédouin, M. Allain, P. Macaudière, S. Deutsch SAE Paper 04-01-1274 (2004).

[17] A. Trovarelli, F. Zamar, J. Llorca, C. De Leitenburg, G. Dolcetti, J. T. Kiss, J. Catal. 169 (1997) 490.

[18] D. Duprez, C. Descorme in "Catalysis by Ceria and Related Materials" (A. Trovarelli, Ed.), Chapter 7, p. 243-280, Imperial College Press (2002).

[19] J. Barbier, D. Bahloul, P. Marécot, J. Catal. 137 (1992) 377.

[20] D. Martin, D. Duprez, Appl. Catal. A, 131 (1995) 297.

[21] A. M. Pisanu, C. E. Gigola, Appl. Catal. B 11 (1996) L37.

[22] A. Douidah, P. Marécot, S. Szabo, J. Barbier, Appl. Catal. A 225 (2002) 21. 
[23] H. Yoshida, Y. Yazawa, T. Hattori, Catal. Today 87 (2003) 19.

[24] A. Holmgren, B. Andersson, D. Duprez, Appl. Catal. 22 (1999) 215.

[25] S. Rossignol, C. Descorme, C. Kappenstein, D. Duprez, J. Mater. Chem. 11 (2001) 2587.

[26] S. Bedrane, C. Descorme, D. Duprez, Catal. Today, 75 (2002) 401.

[27] J. Soria, A. Martinez-Arias, J. Conesa, J. Chem. Soc. Faraday Trans. 91 (1995) 1669.

[28] C. Li, K. Domen, T. Maruya, T. Onishi, J. Am. Chem. Soc. 111 (1989) 7683.

[29] C. Descorme, Y. Madier, D. Duprez, J. Catal. 196 (2000) 167.

[30] C. Li, Y. Sakata, T. Arai, K. Domen, K. Maruya, T. Onishi, J. Chem. Soc. Faraday Trans. 185 (1989) 929; C. Li, Y. Sakata, T. Arai, K. Domen, K. Maruya, T. Onishi, J. Chem. Soc. Faraday Trans. 185 (1989) 1451.

[31] C. Binet, A. Badri, M. Boutonnet-Kizling, J. C. Lavalley, J. Chem. Soc. Faraday Trans. 90 (1994) 1023.

[32] M. Daturi, E. Finnochio, C. Binet, J. C. Lavalley, F. Fally, V. Perrichon, J. Phys. Chem. B 103 (1999) 4884.

[33] A. Norman, V. Perrichon, Phys. Chem. Chem. Phys. 5 (2003) 3557.

[34] T. X. T. Sayle, S. C. Parker, C. R. A. Catlow, Surf. Sci. 316 (1994) 329.

[35] J. C. Conesa, Surf. Sci. 339 (1995) 337.

[36] R. Di Monte, J. Kašpar, J. Mater. Chem. 15 (2005) 633.

[37] S. Bedrane, PhD dissertation, Poitiers University, France, 2002.

[38] D. Martin, D. Duprez, J. Phys. Chem. 100 (1996) 9429.

[39] A. Holmgren, D. Duprez, B. Andersson, J. Catal. 182 (1999) 441.

[40] D. Duprez in "Isotopes in Catalysis" (J. Hargreaves et al. Eds), Chap. 7. Imperial College Press (2006).

[41] R. Kramer, M. Andre, J. Catal. 58 (1979) 287.

[42] D. Duprez, P. Pereira, A. Miloudi, R. Maurel, J. Catal., 75 (1982) 151.

[43] H. Kakioka, V. Ducarme and S. J. Teichner, J. Chim. Phys., 68 (1971) 1715.

[44] A. Galdikas, C. Descorme, D. Duprez, Solid State Ionics, 166 (2004) 147.

[45] A. Galdikas, C. Descorme, D. Duprez, Appl. Surf. Sci. 236 (2004) 342.

[46] A. Galdikas, C. Descorme, D. Duprez, F. Dong, H. Shinjoh, Topics Catal. 30/31 (2004) 405.

[47] D. Duprez, Stud. Surf. Sci. Catal. 112 (1997) 13.

[48] C. Li, K. Domen, K. Maruya, T. Onishi, J. Amer. Chem. Soc. 111 (1989) 7683.

[49] C. Li, K. Domen, K. Maruya, T. Onishi, J. Catal. 123 (1990) 436.

[50] J. G. Nunan, R. G. Silver, S. A. Bradley in "Catalytic Control of Air pollution" (R. G. Silver, J. E. Sawyer, J. C. Summers, Eds), ACS Symposium Series, Vol. 495 Chap. 7 (1992), p. 83.

[51] M. Ozawa, J. Alloys Comp. 275-277 (1998) 886.

[52] V. I. Parvulescu, P. Grange, B. Delmon, Catal. Today, 46 (1998) 233.

[53] Y. F. Yu Yao, Ind. Eng. Chem, Prod. Res. Dev. 19 (1980) 293.

[54] Y. F. Yu Yao, J. Catal. 87 (1984) 152.

[55] C. Serre, F. Garin, G. Belot, G. Maire, J. Catal. 141 (1993) 1.

[56] C. Serre, F. Garin, G. Belot, G. Maire, J. Catal. 141 (1993) 9. 
[57] S. Johansson, L. Österlund, B. Kasemo, J. Catal. 201 (2001) 275.

[58] J. Barbier Jr, D. Duprez, Appl. Catal. B 3 (1993) 61.

[59] J. Barbier Jr, D. Duprez, in "Steam effects in three-way catalysis", a Review. Appl. Catal. B 4 (1994) 105.

[60] L. H. Dubois, P. K. Hansma, G. Somorjai, J. Catal. 65 (1980) 318.

[61] R. Dictor, J. Catal. 109 (1988) 89.

[62] F. Solymosi, L. Volgyesi, J. Rasko, Z. Phys. Chem. 120 (1980) 79.

[63] F. Solymosi, T. Bánsági, E. Novák, J. Catal. 112 (1988) 183.

[64] B. K. Cho, B. H. Shanks, J. E. Bailey, J. Catal. 115 (1989) 486.

[65] G. S. Zafiris, R. J. Gorte, J. Catal. 132 (1991) 275.

[66] J. Kaspăr, C. de Leitenburg, P. Fornasiero, A. Trovarelli, M. Graziani, J. Catal. 146 (1994) 136.

[67] T. P. Kobylinski, B. W. Taylor, J. Catal. 33 (1974) 376.

[68] K. Taylor, in "Catalysis, Science and Technology" (J. R. Anderson, M. Boudart, Eds), Vol. 5 p. 119. Springer Verlag, Berlin (1984).

[69] G. Leclercq, C. Dathy, G. Mabilon, L. Leclercq, in "Catalysis and Automotive Pollution Control CaPoC 2" (A. Crucq, Ed.). Stud. Surf. Sci. Catal. 71 (1991) 181.

[70] H. Muraki, G. Zhang, Catal. Today, 63 (2000) 337.

[71] J. L. Duplan, H. Praliaud, in "Catalysis and Automotive Pollution Control CaPoC 2" (A. Crucq, Ed.). Stud. Surf. Sci. Catal. 71 (1991) 667.

[72] N. K. Pande, A. T. Bell, J. Catal. 98 (1986) 7.

[73] W. C. Hecker, N. D. Wardinsky, P. G. Clemmer, P. B. Rasband, in "Progress in Catalysis". Proc. 12 $2^{\text {th }}$ Canadian Symp. Catal. (K. J. Smith and E. C. Sanford, Eds). Stud. Surf. Sci. Catal. 73 (1992) 211.

[74] S. H. Oh, J. Catal. 124 (1990) 477.

[75] S. H. Oh, C. C. Eickel, J. Catal. 128 (1991) 526.

[76] S. H. Oh, J. E. Carpenter, J. Catal. 101 (1986) 114.

[77] L. Pirault, P. Marecot, unpublished results.

[78] G. Djega-Mariadassou, F. Fajardie, J.-F. Tempère, J.-M. Manoli, O. Touret, G. Blanchard, J. Mol. Catal. 161 (2000) 179.

[79] G. Djega-Mariadassou, Catal. Today 90 (2004) 27.

[80] G. Ranga Rao, P. Fornasiero, R. Di Monte, J. Kaspar, G. Vlaic, G. Balducci, S. Meriani, G. Gubitosa, A. Cremona, M. Graziani, J. Catal. 162 (1996) 1.

[81] R. Di Monte, P. Fornasiero, M. Graziani, J. Kaspar, J. Alloys Comp. 275-277 (1998) 877.

[82] P. Fornasiero, G. Ranga Rao, J. Kaspar, F. L'Erario, M. Graziani, J. Catal. 175 (1998) 269.

[83] D. R. Mullins, S. H. Overbury, Surf. Sci. 511 (2002) L293.

[84] V. Schmatloch, I. Jirka, N. Kruse, J. Chem. Phys. 100 (1994) 8471.

[85] M. J. P. Hopstaken, J. W. Niemantsverdriet, J. Phys. Chem. 104 (2000) 3058.

[86] A. Martinez-Arias, J. Soria, J. C. Conesa, X. L. Seoane, A. Arcoya, R. Cataluña, J.

Chem. Soc. Faraday Trans. 91 (1995), 1679..

[87] M. Haneda, Y. Kintaichi, H. Hamada, Phys. Chem. Chem. Phys, 4 (2002) 3146. 
[88] J. J. Lecomte, P. Granger, L. Leclercq, J. F. Lamonier, A. Aboukais, G. Leclercq, Colloids and Surfaces A 158 (1999) 241.

[89] P. Granger, L. Delannoy, J. J. Lecomte, C. Dathy, H. Praliaud, L. Leclercq, G. Leclercq, J. Catal. 207 (2002) 202.

[90] F.B. Noronha, M.A.S. Baldanza, R.S. Monteiro, D.A.G. Aranda, A. Ordine, M. Schmal, Appl. Catal. A 210 (2001) 275.

[91] T. Kolli, K. Rahkamaa-Tolonen, U. Lassi, A. Savimäki, R. L. Keiski, Catal. Today 100 (2005) 297.

[92] J. R. Gonzalez-Velasco, M. A. Guttierez-Ortiz, J. L. Marc, M. Pilar GonzalezMarcos, G. Blanchard, Appl. Catal. B 33 (2001) 303.

[93] Z. Zu, C. Z. Wan, Y. K. Lui, J. Dettling, J. J. Steger, Catal. Today, 30 (1996) 83.

[94] A. Martínez-Arias, M. Fernández-García, A. Iglesias-Juez, A. B. Hungría, J. R. Anderson, J. C. Conesa, J. Soria, Appl. Catal. B 31 (2001) 51.

[95] T. Maunula, J. Ahola, T. Salmi, H. Haario, M. Härkönen, M. Luoma, V. J. Pohjola, Appl. Catal. B 12 (1997) 287.

[96] B. Harrison, M. Wyatt, K. C. Gough, in "Catalysis" (C. Kemball and D. A. Dowden, Eds). Vol. 5 p. 127. The Royal Society of Chemistry, London (1982).

[97] J. C. Vartui, R. D. Gonzalez, Ind. Eng. Chem., Proc. Res. Dev. 12 (1973) 265.

[98] J. W. Ault, R. J. Ayen, AIChE J. 17 (1971) 265.

[99] R. Pérez-Hernández, F. Aguilar, A. Gómez-Cortès, G. Díaz, Catal. Today, 107-108 (2005) 175.

[100] P. Bera, K. C. Patil, V. Jayaram, G. N. Subbanna, M. S. Hegde, J. Catal. 196 (2000) 293.

[101] R. Taha, D. Duprez, N. Mouaddib-Moral, C. Gauthier, in "Catalysis and Pollution Control CaPoC 4" (N Kruse, A. Frennet and J. M. Bastin, Eds), Stud. Surf. Sci. Catal. 116 (1998) 549.

[102] J. Fan, X. Wu, R. Ran, D. Weng, Appl. Surf. Sci. 245 (2005) 162.

[103] S. H. Overbury, D. R. Mullins, D. R. Huntley, L. Kundakovic, J. Catal. 186 (1999) 296.

[104] M. Daturi, N. Bion, J. Saussey, J. C. Lavalley, C. Hedouin, T. Seguelong, G. Blanchard, Phys. Chem. Chem. Phys. 3 (2001) 252.

[105] C. Thomas, O. Gorce, F. Villain, G. Djega-Mariadassou, J. Mol. Cat. A 249 (2006) 71.

[106] C. Thomas, O. Gorce, C. Fontaine, J. M. Krafft, F. Villain, G. Djega-Mariadassou, Appl. Catal. B 63 (2006) 201.

[107] T. Tanabe, M. Hatanaka, R. Tsuji, H. Shinjoh, R\&D Review of Toyota CRDL, Vol. $37, \mathrm{Nr} 3$ (2002) 1.

[108] L F Cordoba, M. Flytzani-Stephanopoulos, C. Montes de Correa, Appl. Catal. B 33 (2001) 25.

[109] C. N. Costa, V. N. Stathopoulos, V. C. Belessi, A. M. Efstathiou, J. Catal. 197 (2001) 350.

[110] C. N. Costa, A. M. Efstathiou, J. Phys. Chem. B. 108 (2004) 2620.

[111] W. S. Epling, L. E. Campbell, A. Yezerets, N. W. Currier, J. E. Parks II, Catal. Rev. 46 (2004) 163. 
[112] T. Nakatsuji, J. Ruotoistenmäki, V. Komppa, Y. Tanaka, T. Uekusa, Appl. Catal. B 38 (2002) 101.

[113] T. Kolli, U. Lassi, K. Rahkamaa-Tolonen, T-J. J. Kikunnen, R. L. Keiski, Appl. Catal. A 298 (2006) 65.

[114] L. F. Liotta, A. Macaluso, G. E. Arena, M. Livi, G. Centi, G. Deganello, Catal. Today 75 (2002) 439.

[115] M. Eberhardt, R. Riedel, U. Göbel, J. Theis, E. S. Lox, Topics Catal. 30/31 (2004) 135.

[116] S. Philipp, A. Drochner, J. Kunert, H. Vogel, J. Theis, E. S. Lox, Topics Catal. 30/31 (2004) 235.

[117] E.C. Corbos, S. Elbouazzaoui, X. Courtois, N. Bion, P. Marecot, D. Duprez, submitted in Topics in Catalysis ( $\mathrm{CaPoC} 7)$.

[118] H.-Y. Lin, C.-J. Wu, Y.-W. Chen, C.-H. Lee, Ind. Eng. Chem. Res. 45 (2006) 134. [119] M. Machida, D. Kurogi, T. Kijima, Catal. Today, 84 (2003) 201. 